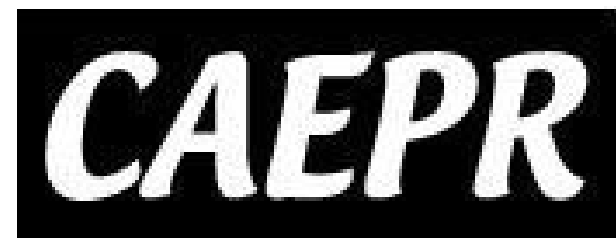

Center for APPLIED ECONOMics and Policy Research

\author{
CAEPR \\ Working Paper \\ \#2017-009
}

\title{
Cyclicality of Hours Worked by Married Women and Spousal Insurance
}

Kathrin Ellieroth Indiana University

August 7, 2017

This paper can be downloaded without charge from the Social Science Research Network electronic library at https://papers.ssrn.com/abstract_id=3023554

The Center for Applied Economics and Policy Research resides in the Department of Economics at Indiana University Bloomington. CAEPR can be found on the Internet at: http://www.indiana.edu/ - caepr. CAEPR can be reached via email at caepr@indiana.edu or via phone at 812-855-4050.

(C)2017 by Kathrin Ellieroth. All rights reserved. Short sections of text, not to exceed two paragraphs, may be quoted without explicit permission provided that full credit, including (c) notice, is given to the source. 


\title{
Cyclicality of Hours Worked by Married Women and Spousal Insurance
}

\author{
Kathrin Ellieroth* \\ Indiana University
}

August 23, 2017

\begin{abstract}
I document that married women's hours worked are significantly less cyclical than hours worked by married men and singles and argue that spousal insurance contributes to the low cyclicality. Analyzing volatility, transition rates, and household behavior, I show that (i) married women experience the lowest cyclical volatility; (ii) their volatility depends more on past than current fluctuations of business cycle indicators; (iii) married women are less likely to become unemployed or leave the labor force during recessions, but not more likely to join the labor force; and (iv) unemployment of the husband is associated with more hours worked by the wife, particularly during recessions.
\end{abstract}

JEL: D13, E32, J12, J22

*Address: Department of Economics, Indiana University, 100 South Woodlawn Avenue, Bloomington, IN 47405, USA. Email: kelliero@indiana.edu. Phone: 812-360-3018 


\section{Introduction}

Literature and data have shown and assumed that aggregate hours worked display a strong procyclical behavior, i.e. we expect hours to decrease during downturns and increase during expansionary phases of the business cycle. However, data for the United States for the previous three decades shows that this is not necessarily the case when disaggregating hours worked by gender and marital status. In particular, I document in this paper that average weekly hours worked for married women appear to be significantly less cyclical than hours worked by married men and single individuals. Figure 1 shows the detrended annual series of weekly hours worked in the United States between 1988 and 2015 for married men, married women, single men, and single women, where the shaded areas indicate NBER recession periods. ${ }^{1}$ It is apparent from figure 1 that single men and single women have the highest cyclicality in their hours worked, whereas married men and married women experience lower volatility. Observing in particular the recent recession, married women have the lowest hours worked volatility compared to married men and single individuals.

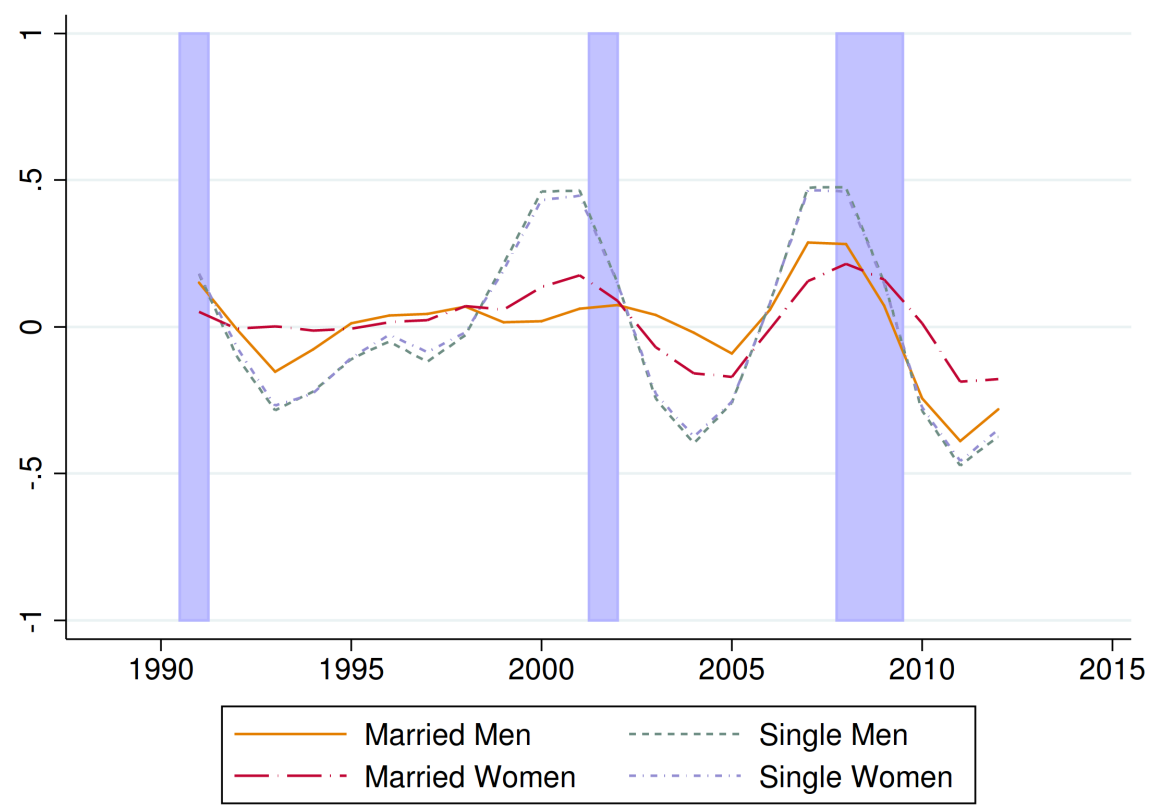

Figure 1: Cyclical component of weekly hours worked by gender and marital status in the United States (filtered series using a band-pass filter)

In this paper I, first, show that married women indeed differ significantly from married men and single individuals with respect to their aggregate labor supply over the business cycle, sec-

\footnotetext{
${ }^{1}$ Doepke and Tertilt (2016) find a similar pattern using HP-filtered data from the Current Population Survey from 1962 until 2014.
} 
ond, analyze the margins determining the low hours worked volatility, and lastly, provide evidence that spousal insurance contributes to the observed low cyclicality of hours worked for married women. The main findings are (i) married women and married men are characterized by similar total volatility of hours worked, but married women experience significantly lower cyclical volatility, i.e. volatility related to business cycle fluctuations, than married men and singles; (ii) for married women the share of total volatility that is due to cyclical volatility is smallest; (iii) hours worked volatility for married women is higher with respect to lagged fluctuations in business cycle indicators; (iv) a flow based analysis shows that married women are more likely to stay employed during recessions and less likely to leave to the labor force during recessions than married men and singles, whereas they are equally likely to join the labor force during recessions; (v) unemployment of the husband is associated with more hours worked by the wife, especially during recessions.

This paper argues that married women whose husbands experience negative labor supply or wage shocks increase their hours worked ${ }^{2}$ in response to the negative shocks. During recessions, this group will offset the procyclical behavior of all married women and dampen the volatility in aggregate hours worked. Thus, leading to the observed low hours worked volatility for married women. Since spousal insurance can take different forms, in the following, I define spousal insurance as adjustments of labor supply by one spouse in response to labor supply or wage shocks faced by the other spouse.

Numerous studies ${ }^{3}$ have documented the existence of an added-worker effect, i.e. the less attached spouse, usually the wife, joins the labor force in response to a negative wage shock to the other spouse, usually the husband. This paper shows that not only labor supply adjustments by married women on the extensive margin contribute to differences in cyclical volatility, but also the intensive margin plays an important role in explaining the low cyclicality. Furthermore, analyzing transition rates between labor market states illustrates that married women differ from married men and single individuals in dimensions other than flows from not-in-the-labor force into unemployment (the added-worker effect). Thus, in order to understand hours worked cyclicality of married women, different margins as well as both stocks and flows need to be considered.

While the subsequent sections of the paper provide more formal evidence for the connection of the business cycle behavior of married womens' aggregate hours worked and spousal insurance, data from the Current Population Survey illustrates, that in particular in the recent recession,

\footnotetext{
${ }^{2}$ I include starting a job, i.e. adjustments on the extensive margin, into the term "increase hours worked"

${ }^{3}$ Beginning with the seminal work by Lundberg (1985)
} 
households adjusted labor supply and allocation choices in a way that indicates the importance of spousal insurance during recessions and thus, leads to the observed low hours worked cyclicality for married women.

Smith (2012) points out in a recent study that recessions change the contribution of spouses to household earnings. In all three recessions since 1988 wives' contribution to total family earnings increased relative to pre-recession rates with the biggest increase in the recent recession. Between 2008 and 2009 wives' contribution to family earnings increased by 2 percentage points, constituting the largest increase over the period of one year since 1988. Figure 2 highlights that not only wives' contribution to total family earnings increases during recessionary periods but also wives' contribution to total hours worked within the household. While both observations might be due to losses in husbands' incomes or hours rather than increases in wives' incomes or hours, the figures illustrate the importance of spouses in recessions. Even if wives were to not respond at all to negative wage shocks faced by their husband, the sole presence of a second-earner constitutes a form of insurance.

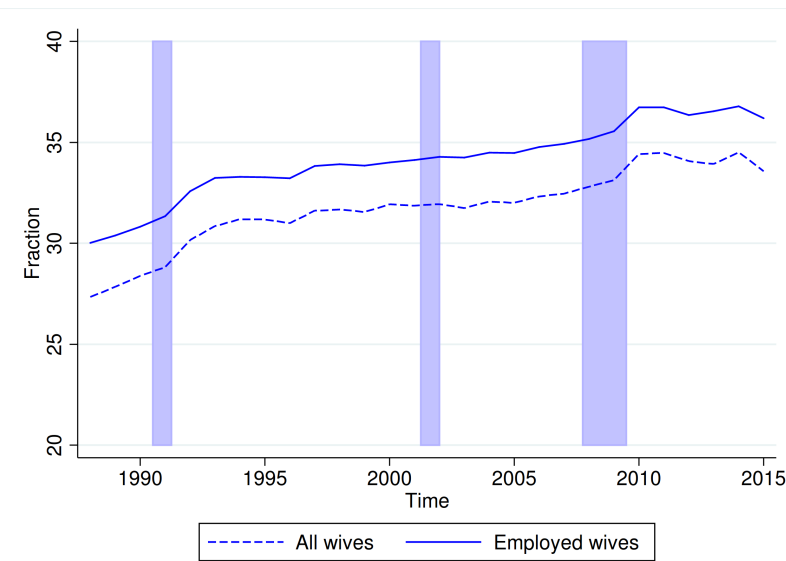

(a) Wives' contribution to total family earnings

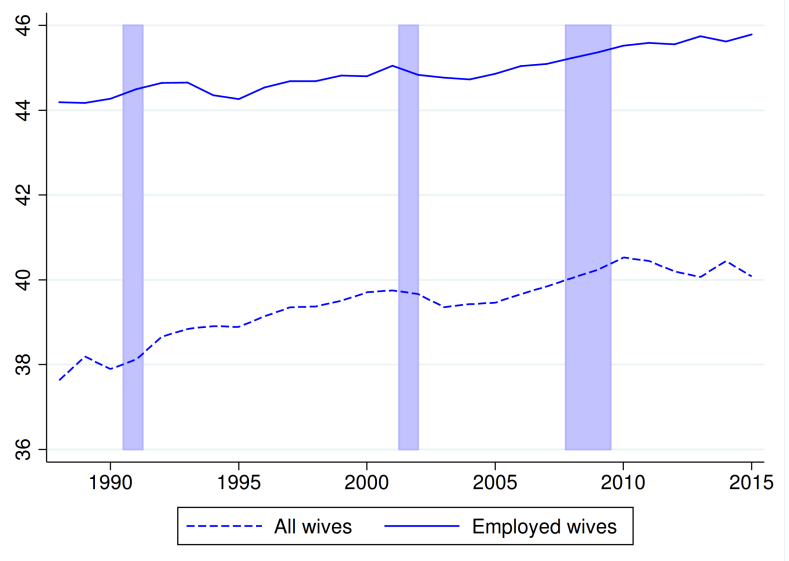

(b) Wives' contribution to total household hours worked

Figure 2: Wives' contribution to household earnings and hours worked over the business cycle (CPS March Supplement data: author's own calculations)

However, figure 3 shows that there indeed seem to be responses in labor supply decisions by married women during recessions. Vespa, Lewis, and Kreider (2013) in a U.S. Census Bureau report find that the percentage of stay-at-home mothers dropped during the 2007-2009 recession, while the percentage of stay-at-home fathers remained constant throughout the recession. Figure 3 illustrates that the fraction of stay-at-home mothers drops before and during recessions but returns 
to its pre-recession numbers during expansionary periods, whereas there are hardly any changes in the fraction of stay-at-home fathers. This procyclicality in the fraction of stay-at-home mothers not only supports the hypothesis that spousal insurance contributes to the low cyclicality of married women's hours worked, but also, that even in the presence of children households rely on the second worker during economic downturns.

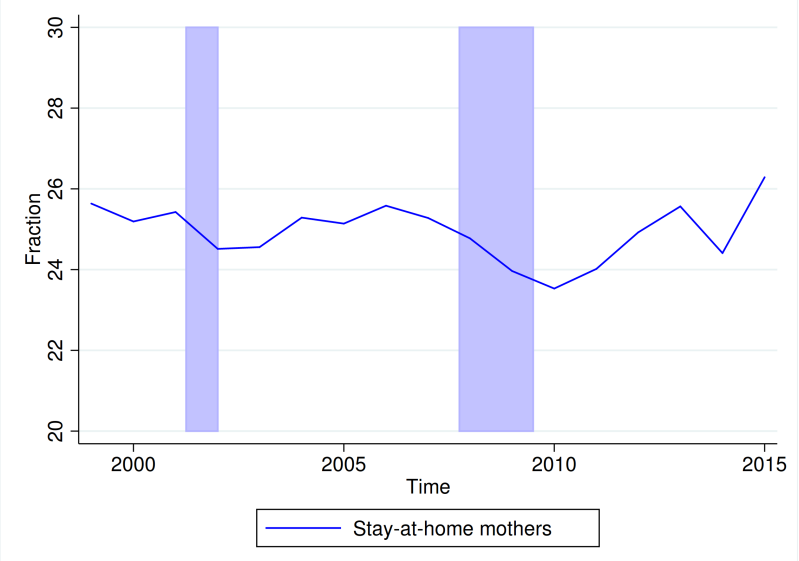

(a) Fraction of stay-at-home mothers

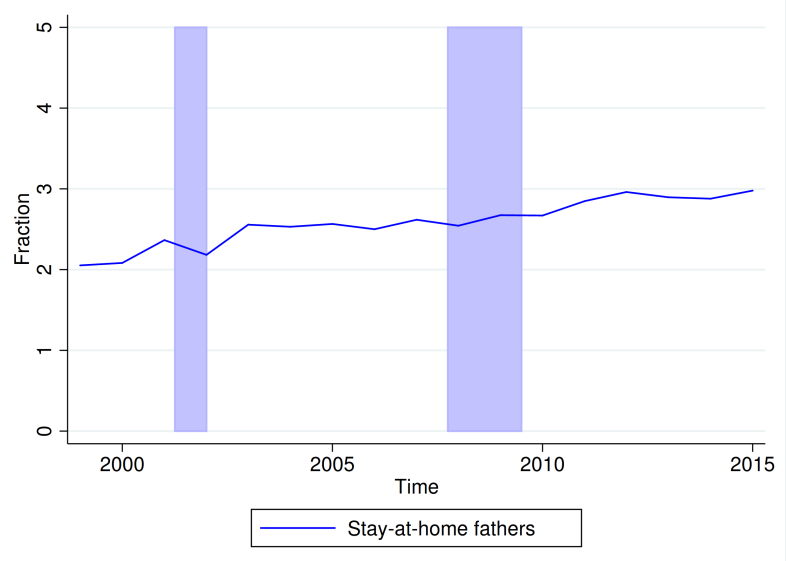

(b) Fraction of stay-at-home fathers

Figure 3: Stay-at-home parents over the business cycle (CPS March Supplement data: author's own calculations)

\section{$1.1 \quad$ Related Literature}

This paper relates to two strands in the literature. First, this paper relates to the research focusing on business cycle volatility and the contribution of different demographic groups. Jaimovich and Siu (2009) examine the relative importance of different age groups to changes in business cycle volatility in the U.S. and Europe and find that the workforce age composition has a significant impact on aggregate business cycle volatility over the recent decades. This paper uses their proposed method to illustrate that business cycle volatility crucially depends on both gender and marital status. Doepke and Tertilt (2016) similar to this paper point out that married women have a lower aggregate labor supply volatility than married men and single individuals. At the same time they find an increase in the labor force participation rate for women and argue that this trend in the female labor force participation rate has a dampening effect on total labor supply, mainly driven by married women. Choi and Valladares-Esteban (2017) use a flows based decomposition and find that married individuals, on average, face a lower unemployment rate than singles. This unemployment gap between married and single individuals exhibits countercyclical behavior. 
Second, this paper contributes to the research in the past decades investigating and testing the added-worker effect, i.e. research studying whether married women adjust their labor supply on the extensive margin in response to a negative wage shock faced by their husbands. Starting with the paper by Lundberg (1985), it has been well empirically documented that a negative wage shock faced by one spouse (usually the husband) induces labor supply responses of the other spouse (usually the wife). The added-worker effect literature focuses primarily on the employment decision by the wife, and usually abstracts from considering labor supply adjustments on the intensive margin. This paper is closely related to Mankart and Oikonomou (2016a), who explain the acyclicality of the labor force participation rate in the United States by the countercyclicality of the labor force participation rate for married women. Similar to my paper, the authors argue that the addedworker effect is the driving force behind the countercyclicality of the labor force participation rate for married women. However, Mankart and Oikonomou (2016a) only focus on the labor force participation rate and therefore, on the extensive margin, and abstract from any other dimensions of labor suppy adjustment. Juhn and Potter (2007) also use the March CPS survey and find evidence for the added-worker effect, however, since the number of non-participating wives has declined in the past decades, they find a less important role for intra-family risk-sharing. Similarly, Starr (2014) and Gorbachev (2016) study the added-worker effect using the American Community Survey and PSID, respectively, during the Great Recession. While Gorbachev (2016) finds that families no longer rely on spousal insurance but rather use other (more formal) insurance mechanisms, Starr (2014) finds that married women are more likely to be employed during the Great Recession if their husbands become unemployed. The empirical studies investigating the added-worker effect support my hypothesis in that spouses insure each other when facing negative wage shocks, in particular, when the primary earner, usually the husband, faces negative earnings shock. This paper, however, not only considers responses on the extensive margin, but finds evidence that even when conditioning on working married women, married women differ in their labor supply cylicality.

\subsection{Structure of the Paper}

This paper is structured as follows. The following section illustrates my data sources, my sample selection, the matching procedure of different data sources, as well as the filtering method I use to detrend the data. In section 3, I focus on aggregate volatility of hours worked. The section describes my empirical method to separate aggregate from cyclical volatility and presents results substantiating my observation regarding differences in aggregate hours worked volatility by gender 
and marital status. Furthermore, the section explores the differences in timing of labor supply decisions for married women, married men, and single individuals. Lastly, section 3 analyzes the contribution of different margins to the volatility of aggregate hours worked and calculates transition rates between different labor market states. Section 4 discusses estimation isses and my methodology I use to test my hypothesis using micro data. Section 5 discusses my results and section 6 concludes.

\section{Data and Filtering Methods}

\subsection{Data}

In the following, I use data from the Current Population Survey (CPS) between 1988 and 2015. I use both the Annual and Social Economic (ASEC) $)^{4}$ file as well as the basic monthly data files. The CPS is the main data source covering the labor market in the United States and it contains information about employment, earnings, and other individual and household characteristics of about 50,000 to 60,000 households each month representing the noninstitutional population of the United States. The ASEC supplement additionally contains information about work experience, income, and hours per week worked for about 90,000 households every year. While the basic CPS files survey households every month, the ASEC supplement is collected annually (every March).

A great advantage of the CPS ASEC supplement for my purpose is that it contains information for each person in the household and it provides detailed information about the number of hours worked as well as information about the current desire to work, reason for not working, and intentions for job seeking for both spouses in the household. Furthermore, the CPS allows for the possibility of matching the CPS main monthly files across a total of 8 months, matching the CPS ASEC supplement across two consecutive years, or matching the CPS supplement and the CPS main monthly files across 4 consecutive months.

In the following, I only use individuals that are between 25 and 65 years old and are not members of the Armed Forces. I choose the age bounds in order to exclude effects from education and because I abstract from retirement decisions and any effects of retirement in this paper. Due to the structure of the CPS, I only include married couples where both spouses are present and live at the same physical address, since only household members living at the same address can be matched. For my calculation on aggregate volatility I will also look at single individuals. The

\footnotetext{
${ }^{4}$ Before 2003 known as the Annual Demographic File (ADF), also known as the March supplement
} 
term single is a broad one in the sense that it refers to "not married" and includes never married, divorced, as well as widowed individuals.

\subsubsection{Matching across years and months}

I exploit the panel structure offered in the CPS in my estimations to control for timing effects as well as to include information which is provided in the CPS monthly files but not in the March supplement. Furthermore, I match the CPS main monthly files across two months in order to calculate the transition rates between different labor market states.

All households in the CPS are interviewed for four consecutive months, are rotated out for eight months, and then again interviewed for four consecutive months. This allows for matching households in the following three ways; (i) Households surveyed in the monthly data files can be matched for 4 consecutive months and up to a total of 8 months; (ii) About half of all households interviewed in the CPS March Supplement can be matched with next year's CPS March Supplement, while the other half can be matched with the previous year's CPS March Supplement; (iii) A fraction of households observed in the CPS March supplement can be matched with the basic monthly files in the previous three months.

However, there are a couple issues involved with matching households both across years and across months. First, the unique household identifier in the CPS corresponds to the physical location of the household, thus, researchers can only identify and match households that have not moved during the particular year or month. Following Madrian and Lefgren (1999), I use type of household, and sex and age of the household members, features that should not change between months and years, as indicators to check for match quality. Unfortunately, as noted by other users of the CPS, this reduces the number of households available to match by about $30 \%$, in particular in later years. While this lowers the possibility of having false matches, it also eliminates couples that could have been matched. Due to initial false reports in sex or a change in male-headed to female-headed household, I might reject a couple although I could have observed and matched it. A second issue is that some years of the CPS March supplement as well as the basic monthly files can not be matched due to significant changes in the census design sample. It is not possible to match the CPS March supplements between 1995 and 1996 because of a change in the design sample. Furthermore, the Census Bureau changed the industry and occupation classification system in 2002, which makes industry and occupation information before and after 2003 not comparable. Third, the census bureau "oversamples" households in the ASEC supplement, which means the census 
bureau not only interviews households participating in the March basic monthly files, but also households that were interviewed in other months. Thus, only households that are also interviewed in the March basic monthly file can be matched to the March supplement. Furthermore, Flood and Pacas (2016) point out that due to the oversampling, some household identifiers in the ASEC files are duplicate and these households cannot be included in the analysis either.

\section{$2.2 \quad$ Filtering methods}

Hours worked for married women are characterized by an upward trend in the 1980s and 1990s, whereas hours worked by married men have been declining over the recent decades. In order to abstract from these trends, I use two different filtering methods to detrend my data. Using both provides a robustness check with respect to the observed low volatility of married women's hours worked actually driven by their decisions and not a particular filtering method.

I will use a band-pass filter following the method proposed by Baxter and King (1999) as my main filtering method to detrend the data on hours worked and other labor market outcomes. As a robustness check and due to its popularity in the literature and similar studies, I use the HodrickPrescott (HP) filter. For the annual aggregated data I choose an order of 3 for the symmetric moving average in the band-pass filter, and a smoothing parameter of 6.25 for the HP filter.

\section{Macro Evidence}

This section establishes the pattern regarding hours worked by gender and marital status, as seen in figure 1, empirically. I start by examining correlations between hours worked and business cycle indicators to explore the degree of cyclicality. While GDP per capita is frequently used as a measure of the business cycle and NBER recessions are defined according to changes in GDP, I look at business cycle indicators directly related to the labor market. Literature has shown that the recent recessions are characterized by a lag of the labor market behind GDP in the recovery after a recession. Hence, looking at correlations between hours worked and GDP distort the correlations since GDP is growing while the labor market is still contracting. ${ }^{5}$

Table 1 shows correlations of hours worked for different groups and the unemployment rate, employment rate, and labor force participation rate, respectively, where the latter two are detrended using a band-pass filter to account for possible trends in the rates. Table 1 shows that the pattern

\footnotetext{
${ }^{5}$ In fact, calculating correlations between hours worked and GDP per capita yields correlations close to zero and for certain time periods even indicates countercyclical hours worked
} 
observed in figure 1 remains the same regardless of the business cycle indicator used. Furthermore,

\begin{tabular}{lcccc}
\hline Business cycle indicator & \multicolumn{3}{c}{ Detrended hours worked series } \\
\hline & Married men & Single men & Married women & Single women \\
\hline Unemployment rate & -0.7214 & -0.6237 & -0.3921 & -0.6121 \\
Employment rate & 0.6588 & 0.6011 & 0.4167 & 0.5922 \\
Detrended employment rate & 0.8494 & 0.8247 & 0.6365 & 0.8122 \\
Detrended labor force participation rate & 0.5892 & 0.8140 & 0.7740 & 0.8107 \\
\hline
\end{tabular}

Table 1: Correlation of hours worked (detrended series using band-pass filter) and business cycle indicators

it is apparent from table 1 that married women experience the lowest correlation of hours worked with any of the business cycle indicators compared to married men, single men, and single women.

\subsection{Total vs. cyclical volatility}

This section separates volatility of the detrended hours worked series into total volatility and cyclical volatility modifying Jaimovich and Siu (2009) and Doepke and Tertilt (2016). I depart from Jaimovich and Siu (2009) and Doepke and Tertilt (2016) in three important ways. First, I use a different filtering method, in particular, I use a band-pass filter rather than the Hodrick-Prescot filter. Second, I use the unemployment rate as my business cycle indicator rather than GDP per capita due to the lagging of the labor market behind GDP in the recent recessions in the United States. Lastly, I account for possible delays in the response of hours worked to wage or labor supply shocks and will look at a measure of lagged cyclical volatility.

Total volatility then is the percentage standard deviation of the detrended hours worked series by gender and marital status from trend. Cyclical volatility is the percentage standard deviation of a projection of the detrended hours worked series by gender and marital status on the unemployment rate from trend, where the linear projection ${ }^{6}$ is

$$
\operatorname{hours}_{t}^{g, r}=\beta_{0}+\beta_{1} \text { unemployment } \text { rate }_{t}+\varepsilon_{t}
$$

where $g=m, f$ indicates male or female and $r=m, s$ indicates married or single. From the linear projection, I compute cyclical volatility as the percentage standard deviation of $\widehat{\text { hours }}_{t}^{g, r}$ from trend. Thus, cyclical volatility only captures the share of total volatility that is due to (or correlated with) business cycle fluctuations in the unemployment rate.

\footnotetext{
${ }^{6}$ Since, in general, a linear predictor for $y$ conditional on $x$ is any linear function $x^{\prime} \beta$
} 
Table 2 displays my results regarding hours worked volatility of men and women as well as married and single individuals. For comparison with other studies I use both a band-pass filter as well as the Hodrick-Prescott filter. It is apparent from table 2 that the pattern is similar for both types of filtering methods. Overall total volatility is lower in levels for all groups when using the band-pass filter. However, the relative differences in volatility between groups are the same in both filtering methods. The reason total volatility is lower when using the band-pass filter is that this filter not only filters low frequencies, but also high frequencies, whereas the high-pass filter only filters low frequencies. Moreover, although probably a minor reason, in order to filter the data using the band-pass filter, I have to discard $k$ periods at the beginning and the end of the sample. ${ }^{7}$

I differentiate between individuals who work at least one hour in a week, which I refer to as intensive margin, from all individuals in the working-age population, which I combine into intensive and extensive margin. Not surprisingly, volatility is higher when including everyone since starting or quitting a job usually implies a greater change in hours worked, whereas adjustments on the intensive margin are smaller.

\begin{tabular}{lcc|cc||cc|cc}
\hline & \multicolumn{7}{c}{ Band-Pass Filter } & \multicolumn{3}{c}{ Hodrick-Prescott Filter } \\
\hline & Men & Women & Married & Single $\|$ & Men & Women & Married & Single \\
\hline & \multicolumn{7}{c}{ Intensive margin } \\
\hline Total Volatility & 0.2487 & 0.2413 & 0.1880 & 0.3014 & 0.3263 & 0.3172 & 0.2384 & 0.3706 \\
\hline Cyclical Volatility & 0.2150 & 0.1236 & 0.1598 & 0.2188 & 0.2219 & 0.1241 & 0.1625 & 0.2281 \\
$R^{2}$ & 74.70 & 26.22 & 72.75 & 52.74 & 46.25 & 15.31 & 46.47 & 37.90 \\
Share & 0.86 & 0.51 & 0.85 & 0.73 & 0.68 & 0.39 & 0.68 & 0.61 \\
\hline & & \multicolumn{7}{c|}{ Intensive and extensive margin } \\
\hline Total volatility & 0.5333 & 0.5517 & 0.3693 & 0.8902 & 0.6983 & 0.6661 & 0.4822 & 1.0457 \\
\hline Cyclical volatility & 0.3522 & 0.1931 & 0.1481 & 0.3959 & 0.2927 & 0.1716 & 0.1392 & 0.4751 \\
$R^{2}$ & 43.62 & 12.25 & 24.19 & 31.28 & 17.57 & 6.63 & 8.33 & 20.64 \\
Share & 0.66 & 0.35 & 0.40 & 0.44 & 0.42 & 0.26 & 0.29 & 0.45 \\
\hline
\end{tabular}

Table 2: Total and cyclical volatility by gender and by marital status

In the following, let me discuss the striking features of total and cyclical volatility in table 2 . First, a comparison of men and women, for both filtering methods as well as both margins, shows that both groups display a very similar total volatility of hours worked over the business cycle in my sample. A comparison of married and single individuals, however, shows that total volatility of hours worked in the aggregate depends on the marital status of the individual since married

\footnotetext{
${ }^{7}$ In this case, I choose $k=2$
} 
individuals experience significantly lower volatility in hours worked than single individuals.

Next, looking at cyclical volatility, i.e. the volatility correlated with fluctuations in business cycle indicators, shows a very different picture for men and women compared to the total volatility results. Volatility in hours worked is no longer the same for men and women, but women on average have significantly lower cyclical volatility than men. In both filtering methods and at both margins, cyclical volatility in hours worked for women is about half of the cyclical volatility in hours worked for men. Moreover, the $R^{2}$ shows that fluctuations in the unemployment rate explain less of the variation in detrended hours worked for women than for men. Not only have women lower cyclical volatility than men, but also the share of cyclical volatility in total volatility is significantly lower for women than for men. Only between one fifth and one third of total volatility for women is due to cyclical volatility, whereas around $80 \%$ of total volatility is due to cyclical volatility for men.

Table 3 distinguishes between married men and women and between single men and women. Total volatility is largest for both single men and women. Married men have the lowest total volatility out of the four groups and married women's total volatility in hours worked is slightly higher than for married men but lower than total volatility for single men and single women. However, looking at volatility that is related to the business cycle reveals a very different picture. In terms of cyclical volatility of hours worked, married men, single men, and single women appear to be similar, married women, however, have a significantly lower cyclical volatility than the other groups. Married women experience about half of the cyclical volatility in hours worked than the other groups at the intensive margin for both filtering methods. When additionally including the extensive margin, cyclical volatility is only about a third of what it is for the other groups. Similarly, the share of cyclical volatility of total volatility is about the same for single men and single women. Married men have a significantly higher share whereas married women experience a significantly lower share. Only about $20 \%$ of total volatility is related to business cycle fluctuations in the unemployment rate for married women. Not surprisingly, the $R^{2}$ in the regressions is also lowest for married women indicating that only a small fraction of the variation in hours worked for married women can be explained by fluctuations in the detrended unemployment rate.

My results support the findings by Doepke and Tertilt (2016) and can be summarized in four main findings: (i) Married individuals experience both lower total and lower cyclical volatility than single individuals; (ii) Women display similar total volatility than men, but lower cyclical volatility than men; (iii) Married women experience a significantly lower cyclical volatility than the other three groups, married men's cyclical volatility is in between the cyclical volatility of married women 


\begin{tabular}{|c|c|c|c|c|c|c|c|c|}
\hline & \multicolumn{4}{|c|}{ Band-Pass Filter } & \multicolumn{4}{|c|}{ Hodrick-Prescott Filter } \\
\hline & \multicolumn{2}{|c|}{ Married } & \multicolumn{2}{|c|}{ Single } & \multicolumn{2}{|c|}{ Married } & \multicolumn{2}{|c|}{ Single } \\
\hline & Men & Women & Men & Women & Men & Women & Men & Women \\
\hline & \multicolumn{8}{|c|}{ Intensive margin } \\
\hline Total Volatility & 0.2222 & 0.2506 & 0.3067 & 0.3004 & 0.2854 & 0.3413 & 0.3796 & 0.3696 \\
\hline Cyclical Volatility & 0.1877 & 0.1087 & 0.2085 & 0.1996 & 0.2209 & 0.1059 & 0.2020 & 0.2074 \\
\hline$R^{2}$ & 71.37 & 27.72 & 54.90 & 52.87 & 50.12 & 10.85 & 40.25 & 37.71 \\
\hline \multirow[t]{2}{*}{ Share } & 0.84 & 0.21 & 0.47 & 0.46 & 0.77 & 0.31 & 0.53 & 0.56 \\
\hline & \multicolumn{8}{|c|}{ Intensive and extensive margin } \\
\hline Total volatility & 0.4033 & 0.4391 & 0.9189 & 0.8967 & 0.5542 & 0.5827 & 1.0846 & 1.0513 \\
\hline Cyclical volatility & 0.2344 & 0.0926 & 0.4298 & 0.4100 & 0.1835 & 0.0782 & 0.4258 & 0.3950 \\
\hline$R^{2}$ & 33.78 & 10.00 & 32.19 & 31.95 & 10.97 & 4.08 & 22.73 & 21.67 \\
\hline Share & 0.58 & 0.21 & 0.47 & 0.46 & 0.33 & 0.13 & 0.39 & 0.38 \\
\hline
\end{tabular}

Table 3: Total and cyclical volatility for each gender and marital status combination

and that of single individuals; and (iv) Furthermore, for married women cyclical volatility is the smallest fraction of total volatility compared to the other groups, whereas for married men it is the largest fraction.

\subsection{Does timing matter?}

There are several reasons why the timing of economic shocks and variation in economic variables matters for the labor supply decisions by individuals. It is unlikely to assume that labor supply choices, i.e. number of hours worked, are changed instantaneously when the household or household members face a shock to wage income or labor supply. There are different reasons for the delayed reaction; First, if the spouse only faces a temporary or transitory shock, the other spouse might not decide to adjust her labor supply, since this requires also an adjustment of her outside option, such as home production or child care. Adjusting these might be costly or take time, especially since the shock is transitory and therefore has only little wealth effects. Stephens (2002) analyzes the timing of the added-worker effect to a shock faced by their husbands and finds that timing differs after a negative labor supply shock to the husband dependent on the type of unemployment. Second, the household might rely on other mechanisms to smooth consumption and insure themselves against the negative income shock. Households might use savings or outside insurance before changing and reallocating time between the spouses and market work and outside options. Blundell, Pistaferri, and Saporta-Eksten (2016b) argue that while family labor supply 
appears to be an important insurance mechanism, it is particularly important for low-income families or those that are liquidity constrained, since they do not have access to self-insurance through borrowing. Hence, the response in spousal labor supply is greater for those that do not have other insurance options. Lastly, even if the spouse reacts immediately to an income loss, frictions in the labor market might cause a delay in the actual change in hours worked. I argue that especially in recessionary times, married women respond to unemployment by their husband by increasing their hours. But recessions usually have a negative impact on the labor market and, thus, it may take time for the woman to find a job.

Tables 4 and 5 present a measure of lagged cyclical volatility by gender and marital status. I follow the approach described in the previous section, however, rather than projecting the detrended hours worked series on the contemporaneous unemployment rate, I will project the detrended hours worked series on lags of the unemployment rate. This means that cyclical volatility reports the volatility of hours worked for the different groups that is related to past fluctuations in business cycle indicators. Since I have annual data for the hours worked series and the unemployment rate, I will lag the unemployment rate by one and two years, respectively, yielding the following linear projections

$$
\operatorname{hours}_{t}^{g, r}=\beta_{0}+\beta_{1} \text { unemployment } \text { rate }_{t-s}+\varepsilon_{t}
$$

where $\mathrm{s}=1,2$ indicates one- or two-year lag, $g=m, f$ indicates male or female and $r=m, s$ indicates married or single. In order to compare volatility related to contemporaneous fluctuations in the unemployment rate and lagged unemployment rates, the following tables include the cyclical volatility computed and reported in the previous section. Table 4 reports cyclical volatility for men

\begin{tabular}{l|cc|cc|cc}
\hline & Contemporaneous & \multicolumn{2}{c}{ Lagged 1 period } & \multicolumn{2}{c}{ Lagged 2 periods } \\
\hline & Men & Women & Men & Women & Men & Women \\
\hline & \multicolumn{7}{c}{ Intensive margin } \\
\hline Cyclical Volatility & 0.2150 & 0.1236 & 0.1729 & 0.1795 & 0.0552 & 0.1301 \\
& 74.70 & 26.22 & 60.54 & 53.78 & 6.30 & 25.46 \\
\hline$R^{2}$ & 0.3522 & 0.1931 & 0.5142 & 0.4799 & 0.3902 & 0.5018 \\
\hline Cyclical volatility & 43.62 & 12.25 & 95.87 & 76.22 & 48.41 & 73.13 \\
$R^{2}$ &
\end{tabular}

Table 4: Cyclical volatility for each gender with respect to lags of the unemployment rate (using band-pass filter) 
and women, where I used a band-pass filter to detrend the hours worked series for both men and women. First, when including individuals that do not work, here the lower panel of both tables, cyclical volatility is higher among all groups when projecting their detrended hours worked series on the lagged unemployment rates. Intuitively, this is plausible, starting a job has a longer delay since the search time is higher and it requires more substantial changes with regards to the outside option, for example home production or child care. The most striking feature of table 4, however, is the difference for women between the contemporaneous and lagged unemployment rate. While women experience significantly lower cyclical volatility with respect to current fluctuations in the unemployment rate than men (about $40 \%$ lower than for men), with respect to the one-year lagged unemployment rate, women seem to experience the same cyclical volatility than men. While cyclical volatility that is due to same-time fluctuations is higher for men, for women cyclical volatility that is due to a one-year lag is higher. This result indicates that while women still seem to experience lower or equal cyclical volatility to men, despite similar total volatility, timing is different for men and women.

Table 5 repeats the computation of cyclical volatility, but further distinguishing men and women by their marital status. For all four groups cyclical volatility that is due to variation in the lagged unemploment rate is higher, but for married women the increase relative to the contemporaneous cyclical volatility is highest. Again, this indicates that there is some delay in the response of hours worked to shocks to wages or labor supply. In particular married women face costs when adjusting their hours worked, even on the intensive margin, due to higher opportunity costs with regards to the outside option. While these results do not point to a reason, they do, however, provide some empirical evidence that timing matters when looking at labor supply decisions and women experience higher cyclical volatility due to past fluctuations in the unemployment rate than men. The results suggest that married women not only differ in the degree of cyclicality but also in the timing of their cyclicality of hours worked.

\subsection{Participation margin vs. Hours volatility}

So far most resarch on spousal insurance focuses on the added-worker effect and the participation margin, i.e. adjustments by spouses on the extensive margin in response to negative wage shocks faced by the other spouse. However, the recent sections illustrate that even when conditioning on working, married women display a significantly lower volatility in aggregate hours worked than the other groups. 


\begin{tabular}{|c|c|c|c|c|c|c|c|c|}
\hline & \multicolumn{4}{|c|}{ Contemporaneous } & \multicolumn{4}{|c|}{ Lagged 1 period } \\
\hline & \multicolumn{2}{|c|}{ Married } & \multicolumn{2}{|c|}{ Single } & \multicolumn{2}{|c|}{ Married } & \multicolumn{2}{|c|}{ Single } \\
\hline & Men & Women & Men & Women & Men & Women & Men & Women \\
\hline & \multicolumn{8}{|c|}{ Intensive margin } \\
\hline Cyclical Volatility & 0.1877 & 0.1087 & 0.2085 & 0.1996 & 0.1709 & 0.1513 & 0.2550 & 0.2486 \\
\hline \multirow[t]{2}{*}{$R^{2}$} & 71.37 & 27.72 & 54.90 & 52.87 & 60.54 & 53.78 & 81.89 & 81.70 \\
\hline & \multicolumn{8}{|c|}{ Intensive and extensive margin } \\
\hline Cyclical volatility & 0.2344 & 0.0926 & 0.4298 & 0.4100 & 0.3674 & 0.2457 & 0.6997 & 0.6735 \\
\hline$R^{2}$ & 33.78 & 10.00 & 32.19 & 31.95 & 86.47 & 70.29 & 86.61 & 87.60 \\
\hline
\end{tabular}

Table 5: Cyclical volatility for each gender and marital status combination with respect to lags of the unemployment rate (using band-pass filter)

Jaimovich, Siu, and Pruitt (2013) show that volatility in hours worked can be decomposed into the hours margin, changes in hours per labor force participant, and the participation margin, changes in the number of labor force participants per capita. While the participation margin accounts for changes in hours due to movements in and out of the labor force, similar to the extensive margin, the hours margin captures elements of both the intensive and extensive margin, since hours could vary due to changes in hours worked by employed individuals or movement between employment and unemployment. Thus,

$$
\text { Average Hours }^{g, r}=\frac{\text { Hours }}{\text { Labor Force }}^{g, r} \times \text { Labor Force Participants }^{g, r}
$$

where $g=m, f$ indicates male or female and $r=m, s$ indicates married or single. Taking logs,

$$
\log (\text { Average Hours })^{g, r}=\log \left(\frac{\text { Hours }}{\text { Labor Force }}^{g, r}\right)+\log \left(\text { Labor Force Participants }{ }^{g, r}\right)
$$

the variance of average log hours can be decomposed as follows

$$
\operatorname{Var}\left(\mathrm{hpc}^{g, r}\right)=\operatorname{Var}\left(\mathrm{hplf}^{g, r}\right)+\operatorname{Var}\left(\operatorname{lfpr}^{g, r}\right)+2 \operatorname{Cov}\left(\mathrm{hplf}^{g, r}, \operatorname{lfpr}^{g, r}\right)
$$

where $\mathrm{hpc}^{g, r}$ refers to average log hours worked (or hours per capita), hplf ${ }^{g, r}$ is the share of $\log$ hours per labor force participant, what Jaimovich, Siu, and Pruitt (2013) refer to as the hours margin, and $\operatorname{lfpr}^{g, r}$ is the $\log$ labor force participation rate, which is defined as the participation margin by Jaimovich, Siu, and Pruitt (2013). Table 6 illustrates that while for married women the importance of the participation margin to total volatility in aggregate hours worked is greater 


\begin{tabular}{lcccc}
\hline & Married Men & Married Women & Single Men & Single Women \\
\hline \multicolumn{5}{c}{ Cyclical volatility } \\
\hline Cov. not included & 27.31 & 36.32 & 58.53 & 31.65 \\
Cov. included & 41.40 & 36.67 & 54.19 & 40.95 \\
\hline
\end{tabular}

Table 6: Participation margin's share of hours variance

than for married men, it accounts for only $36 \%$. The majority of hours volatility, however, is due to volatility in the hours margin.

I further decompose the hours margin into the contribution of the intensive margin and the contribution of the share of employed individuals in the labor force, where

$$
\text { Hours per labor force participant }{ }^{g, r}=\frac{\text { Employed }^{g, r}}{\text { Labor Force }^{g, r}} \times \frac{\text { Hours }^{g, r}}{\text { Employed }^{g, r}}
$$

and taking logs, yields the following decomposition

$$
\operatorname{Var}\left(\mathrm{hplf}^{g, r}\right)=\operatorname{Var}\left(\operatorname{eplf}^{g, r}\right)+\operatorname{Var}\left(\mathrm{hpe}^{g, r}\right)+2 \operatorname{Cov}\left(\operatorname{eplf}^{g, r}, \mathrm{hpe}^{g, r}\right)
$$

Table 7 shows that for married women the contribution of the share of employed married women

\begin{tabular}{lcccc}
\hline & Married Men & Married Women & Single Men & Single Women \\
\hline \multicolumn{5}{c}{ Cyclical volatility } \\
\hline Cov. not included & 91.68 & 65.21 & 54.12 & 63.08 \\
Cov. included & 85.87 & 62.12 & 52.77 & 57.73 \\
\hline
\end{tabular}

Table 7: Employment margin's share of hours variance

in the labor force contributes less to volatility in hours worked per labor force participant compared to married men. Abouth two-thirds in volatility in hours worked per labor force participant for married women is due to married women moving between unemployment and employment, whereas one-third is due to changes in the hours worked of employed women. Thus, while the extensive margin is important to explain volatility in married women's aggregate hours worked, adjustments on the intensive margin are important and need to be considered as well when analyzing aggregate hours worked volatility and spousal insurance. In particular, the results above allow for the following break-down of hours worked volatility for married women:

- Participation margin: $36 \%$ 
- Employment margin: $42 \%$

- Hours margin: $22 \%$

\subsection{Flows}

The previous section showed that about 78 percent of married women's hours worked volatility can be accounted for by movements between different labor market states while 22 percent is due to adjustments on the intensive margin. Thus, I compute transition rates between employment, unemployment, and not in the labor force (NILF) in order to understand the cyclicality of these rates. I use the short-panel structure of the CPS and match survey respondents across subsequent months following the methodology by the BLS to calculate the gross worker flows for married women, married men, single women, and single men.

In particular, I perform the following steps: (i) I start by matching households across subsequent months by employing the methodology as described in the data section; (ii) After that, I can use the matched data to compute the number of individuals in each labor force state in a given month as well as the flows between labor market states; (iii) While the BLS provides seasonallyadjusted data to compute gross worker flows and transition rates, my raw matched data displays high seasonality. In order to seasonally adjust the data, I use the X-13ARIMA-SEATS seasonal adjustment program from the Census Bureau. ${ }^{8}$ This program software is produced, distributed and maintained by the Census Bureau to seasonally adjust time-series data and is based on the SEATS procedure developed by the Bank of Spain. ${ }^{9}$

Table 8 illustates the flows between the three possible labor market states, employment, unemployment, and not in the labor force (NILF). Each worker flow $I J$, for $I=E, U, N$ and $J=E, U, N$

\begin{tabular}{|l|c|c|c|}
\hline & \multicolumn{3}{|c|}{ Status in current month } \\
\hline Status in previous month & Employed & Unemployed & Not in labor force \\
\hline Employed & EE & EU & EN \\
\hline Unemployed & UE & UU & UN \\
\hline Not in labor force & NE & NU & NN \\
\hline
\end{tabular}

Table 8: Labor force status flows

is simply the number of individuals with labor force state $I$ in the previous month and labor force

\footnotetext{
${ }^{8}$ I tried two procedures when seasonally adjusting the data which yield almost identical results. First, I seasonally adjust the flows in levels and compute the transition rates using the seasonally adjusted flow numbers. Second, I compute the transition rates using the seasonally unadjusted flows and then seasonally adjust the transition rates. Since both give almost identical seasonally adjusted transition rates, the figures display the transition rates using the latter procedure.

${ }^{9}$ See https://www. census.gov/srd/www/x13as/for a detailed description of the software, its uses, and features.
} 
state $J$ in this period.

From this table, following Elsby, Hobijn, and Şahin (2015), I compute the transition rates of the different groups between the three labor market states, as the number of people with labor force status $I$ in the previous month and labor force status $J$ in the current month relative to all individuals with labor force status $I$ in the previous month. Thus, the transition rate between different labor force states for group $g, r$, where $g=m, f$ and $r=m, s$, is $t_{I J}^{g, r}=I J_{t}^{g_{r}} / I_{t-1}^{g, r}$. For example, the transition rate for married women between employment and unemployment in a given month would be $t_{E U}^{m, w}=E U_{t}^{m, w} / E_{t-1}^{m, w}$, such that we can compute the following matrix of transition rates for each sex and marital status group.

\begin{tabular}{|l|c|c|c|}
\hline & \multicolumn{3}{|c|}{ To current month } \\
\hline From previous month & Employment & Unemployment & Not in labor force \\
\hline Employment & $t_{E E}$ & $t_{E U}$ & $t_{E N}$ \\
\hline Unemployment & $t_{U E}$ & $t_{U U}$ & $t_{U N}$ \\
\hline Not in labor force & $t_{N E}$ & $t_{N U}$ & $t_{N N}$ \\
\hline
\end{tabular}

Table 9: Transition rates between labor market states

Figures 4 and 5 show the transition rates comparing married women and married men as well as married women and single women. The first thing to notice is that, similar to the findings by Elsby, Hobijn, and Şahin (2015), the non-participation margin is important during recessions. The transition rate between non-participation and unemployment is increasing by about 2 percentage points during the recent recession, and appears to be highly procyclical over the business cycle. However, married women, married men, and single women all display a very similar cyclicality of the transition rate between non-participation and unemployment. While this is not contradicting the added-worker effect, it shows that this dimension alone is not enough to explain the observed differences in hours worked cyclicality between married women and married men, single women, and single men. In fact, transition rates for married women between unemployment and the other three states and not in the labor force and the other three states are very similar to those of married men and single women. Married women differ from married men and single women, however, in their transition rates from employment to employment, unemployment, and NILF. Both, married men and single women, experience a lower employment-to-employment, higher employmentto-unemployment, and higher employment-to-not in labor force transition rate during the recent recession. For married women, employment-to-employment did not change during the recession, they experienced a smaller increase in the employment-to-unemployment transition rate, and the 


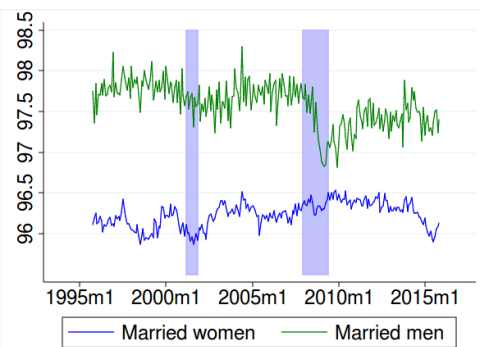

(a) EE

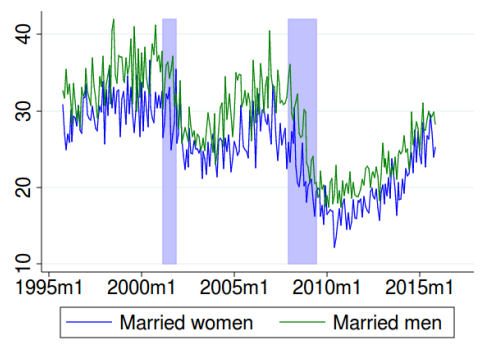

(d) UE

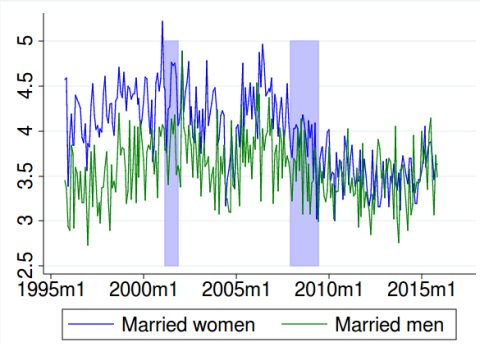

(g) NE

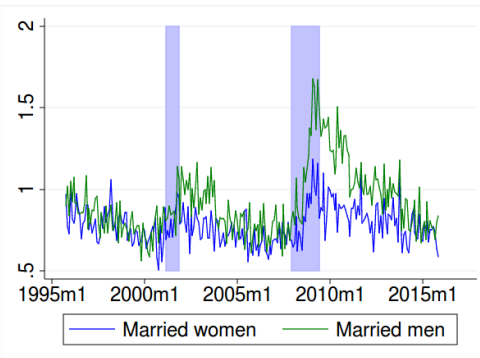

(b) EU

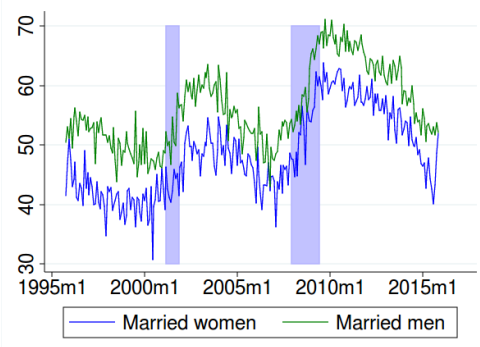

(e) UU

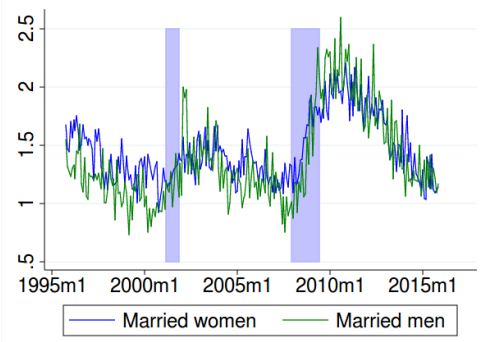

(h) NU

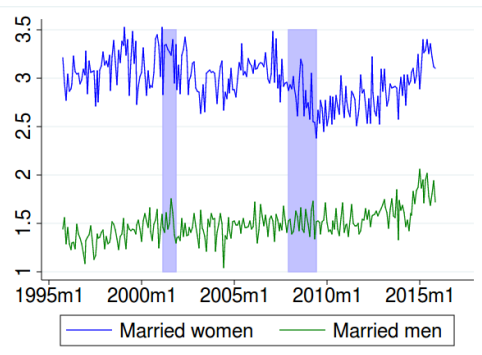

(c) EN

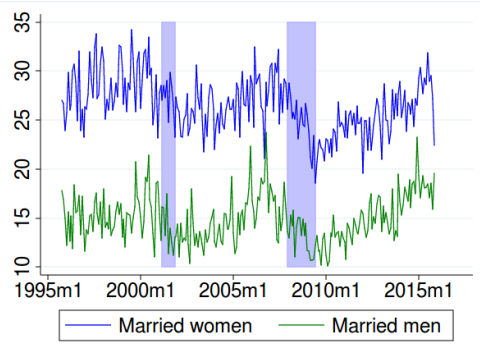

(f) UN

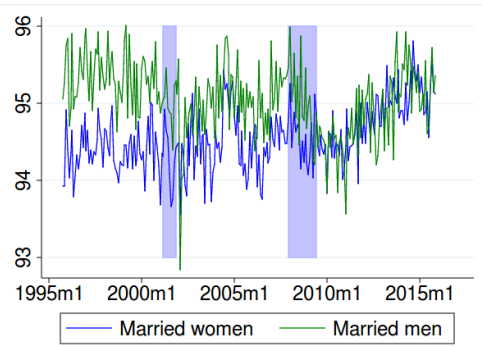

(i) $\mathrm{NN}$

Figure 4: Gross worker flows: Married women and married men

employment-to-not in labor force transition rate actually decreased during the recent recession for married women.

Table 10 illustrates the differences of the flows from employment for married women, married men, and single women in more detail using the total and cyclical volatility definition. Table 10 shows that married women experience lower volatility with respect to their employment-toemployment transition rates than married men and single women. Since employment-to-employment transition rates are generally high, as seen in figures 4 and 5, the differences are small in absolute values, but single women's and married men's volatility in employment-to-employment transition rates is about twice as high as for married women. Married men have the highest employment-tounemployment volatility, about twice as high as for married and single women. With regards to the employment-to-NILF transition rates, however, married men have a significantly lower volatility than married and single women. In figure 4 we saw that the reason for this lower volatility is that 


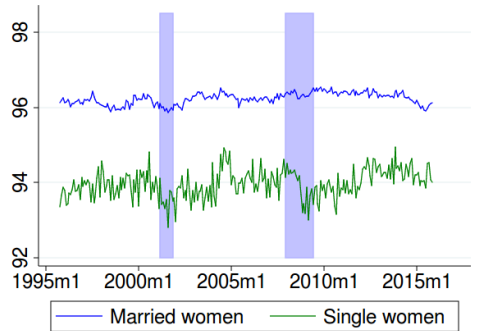

(a) $\mathrm{EE}$

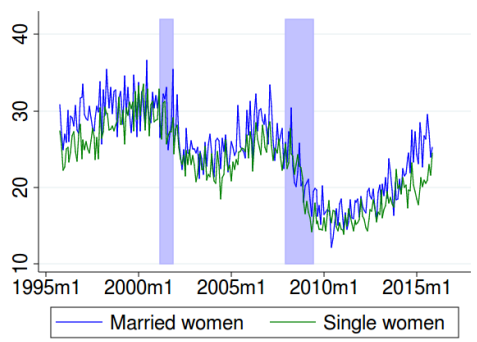

(d) UE

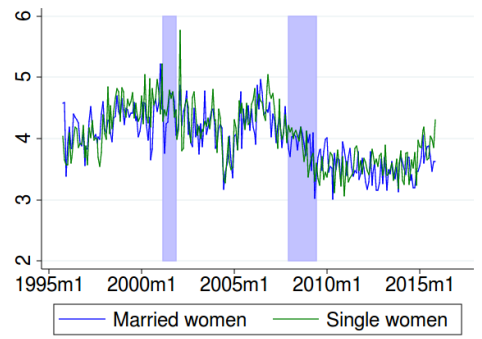

(g) NE

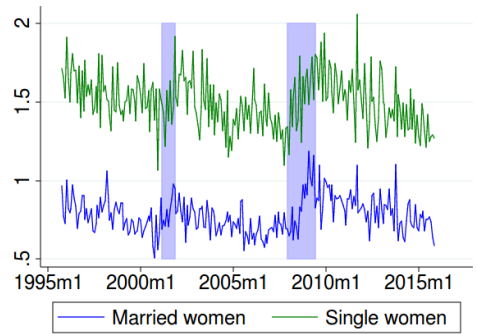

(b) EU

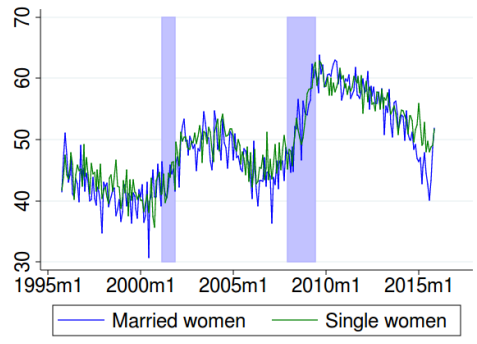

(e) UU

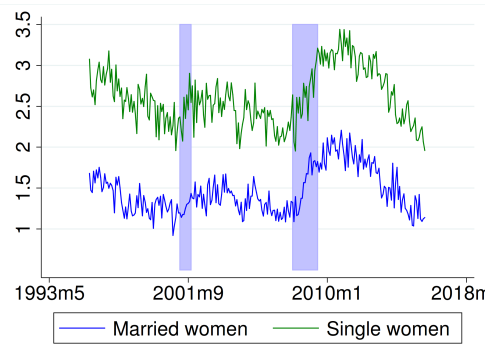

(h) NU

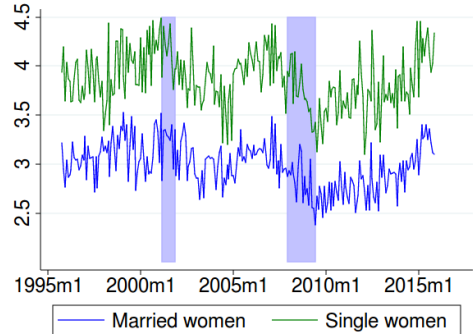

(c) EN

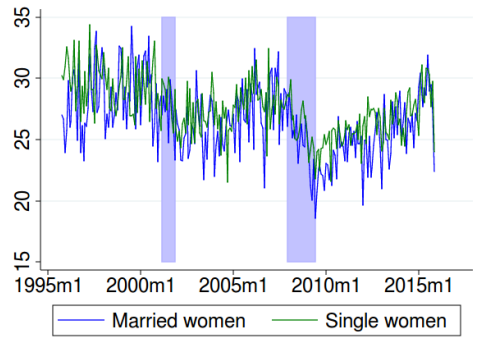

(f) UN

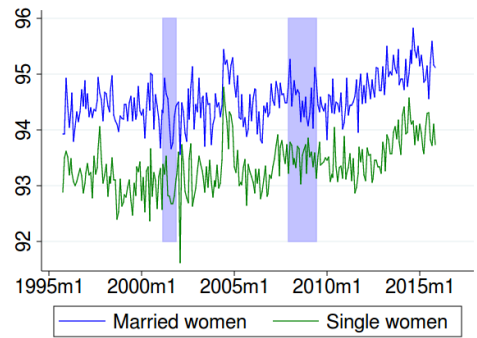

(i) $\mathrm{NN}$

Figure 5: Gross worker flows: Married women and single women

married men's transition rates are mostly unchanged during the recession, whereas for married women the employment-to-NILF transition rates actually decreased. Thus, married women might be equally likely to join the labor force during a recession than married men but are significantly less likely to become unemployed or drop out of the labor force.

\subsection{Other hypotheses}

Studies and research have pointed out that some of the observed differences in labor market outcomes between men and women, such as the business cycle behavior of the unemployment rate, is due to industry and occupation choice of men and women or differences in skill and education. ${ }^{10}$ In particular in the recent recession, also dubbed the "mancession", unemployment rates for men were significantly higher than for women. A frequent reason mentioned for this difference is the different

\footnotetext{
${ }^{10}$ See for example Cerina, Moro, and Rendall (2016)
} 


\begin{tabular}{lccc}
\hline & & \multicolumn{2}{c}{ Total volatility } \\
\hline & Employment-to-Employment & Employment-to-Unemployment & Employment-to-NILF \\
\hline Married women & 0.0907 & 7.6134 & 3.3612 \\
Married men & 0.1325 & 13.9230 & 1.9015 \\
Single women & 0.1509 & 5.1043 & 3.8963 \\
\hline & & Cyclical volatility & \\
\hline Married women & 0.0183 & 5.7508 & 1.9479 \\
Married men & 0.0946 & 11.4616 & 0.8337 \\
Single women & 0.0520 & 3.6779 & 2.6392 \\
\hline
\end{tabular}

Table 10: Total and cyclical volatility of transition rates (Detrended series using a band-pass filter)

occupation and industry choices of men and women and that certain industries were affected more than others. While this is the case in my data as well, this fact alone cannot explain why married women's aggregate hours are different from other groups. If industry or occupation choice were the reason, then one would expect to observe a similar low cyclicality of aggregate hours worked for single women as well. However, the opposite is true, single women experience significantly higher cyclical volatility in hours worked. Tables 15 and 16 in the appendix show that single and married women have an almost identical distribution among different industries and occupations. While industry and occupation choice contributed to some degree, it cannot explain the low cyclicality of aggregate hours worked for married women.

Another factor that could contribute to the observed differences in aggregate hours worked volatility is age. It is possible that single women on average are younger than married women, and most individuals exhibit higher labor uncertainty and risk in earlier stages of the life cycle. Thus, maybe married women have lower cyclicality since they are older than single women. While this might matter to a small degree to the differences in hours volatility, it is unlikely that age is able to explain the difference. If this were true, then one would expect that married men's cyclicality would be similarly low as married women's, which is not the case as seen in the previous section. Furthermore, the age difference between married and single women in the CPS data is only about three years. The average age of married women is 44 years and the average age of single women is 41 years, with a standard deviation of 0.94 and 1.03 , respectively.

Another factor that might contribute to the low cyclicality of married women relative to married men and single women is the higher probability of the presence of young children. Married women are more likely than single women to have children under 18 years old and present in the 
household, and children possibly have a greater impact on married women's labor supply decisions than married men's decision whether and how much to work. While this certainly impacts the decision on the number of hours worked for married women, evidence suggests that married women on average experience low aggregate hours cyclicality despite the presence of children rather than because of the presence of children. Figure 3 showed that the fraction of stay-at-home mothers in the United States exhibits procyclicality, indicating that in recessions mothers with children under 18 years old are less likely to stay at home and join the labor force.

\section{Micro Evidence}

While the previous section examined volatility of aggregate hours worked, in particular, how married women differ in their average labor supply volatility, this section focuses on determinants of individual married women's hours worked decisions. I use the information provided in the CPS March supplement files on labor market outcomes and individual hours worked for spouses as well as information about household and demographic characteristics, which allows me to analyze to what degree spousal insurance, among other factors, contributes to the choice of hours worked for married women.

\subsection{Identification and estimation strategy}

Ideally, I would like to estimate the effect of a change in the husband's employment status on his wife's labor supply decision. Unfortunately, without further assumptions, this would likely yield biased estimates, since simultaneity between the spouses' choices leads to endogeneity. It is likely to assume that the husband's (un)employment status not only affects his wife's hours worked, but also that the hours worked by the wife have an impact on her husband's decision whether to work or not. Labor supply decisions might be made simultaneously, each spouse taking the other spouse's decision into consideration. In the following I will present different estimation strategies that will allow for identification and illustrate the robustness of the effect.

\subsubsection{Conditional mean independence}

First, I argue that the wife's hours worked, conditional on her demographic characteristics, her husband's demographic characteristics, as well as household characteristics, is independent of her husband's labor force status. Thus, I assume the following linear relationship between hours 
worked by the wife $\left(\operatorname{hours}_{i}^{w}\right)$, the (un)employment status of her husband (unemp ${ }^{h}$ ), and other personal demographic characteristics of both spouses, such as wage, age, or education, as well as household characteristics, such as presence of children or household income. Let me combine all personal and household characteristics into the regressor matrix $W_{i}$, such that

$$
\operatorname{hours}_{i}^{w}=\beta_{0}+\beta_{1} \text { unemp }_{i}^{h}+\beta_{2} W_{i}+\varepsilon_{i}
$$

I argue that the conditional expectation of $\varepsilon_{i}$ does not depend on unemp ${ }_{i}^{h}$ once I control for $W$, thus, leading to the following conditional mean independence assumption ${ }^{11}$

$$
\mathbb{E}\left[\varepsilon_{i} \mid \mathrm{unemp}_{i}^{h}, W_{i}\right]=\mathbb{E}\left[\varepsilon_{i} \mid W_{i}\right]
$$

Hence, if we control for, in particular, the wife's age, her education, her wage, her husband's age and wage, the presence and number of children in the household, and total family income, these factors will determine her decision to work and determine her husband's (un)employment status. It is likely to assume that both spouses' labor supply decisions are determined by their wages and total family income, as well as their personal and household characteristics.

The caveat to conditional mean independence, however, is that while it allows for identifying $\beta_{1}$ and the estimations provide an unbiased and consistent estimate of $\beta_{1}$, the other estimates for $W_{i}$ are not necessarily consistent and might not be interpreted as causal effects. The next section illustrates a second identification strategy, which allows for interpreting the other coefficients as causal effects as well, but requires me to reduce the sample of households.

\subsubsection{Unemployment Proxy}

In order to account for the effect of the wife's labor supply decision on her husband's employment status, I separate the husbands that chose unemployment from those that did not choose unemployment. This means, I proxy the unemployment status of the husband in a way such that it only includes unexpected unemployment, which I define as unemployment that was not chosen but due to economic shocks. Thus, I only consider those men to be unemployed, who reported that their unemployment is due to external factors, such as slack work or business conditions, and not a choice. Other reasons for unemployment could be for example child care problems or family/personal obligation. In the case of unexpected or involuntary unemployment, it is unlikely that this

\footnotetext{
${ }^{11}$ See Stock and Watson (2003)
} 
unemployment is impacted by the wife's decision but rather economic shocks. While this requires me to reduce my sample size of households, unexpected or involuntary unemployment is probably a realistic characterization of unemployment over the business cycle. In general, it is likely to assume that most of the business cycle volatility in hours and labor force status is driven by unexpected economic shocks, both individual and aggregate. During recession times the majority of married men in my sample belong to the involuntary unemployed definiton as defined above ${ }^{12}$.

In particular, I will consider those as involuntarily unemployed who answered the following in the CPS survey when asked about their unemployment:

- Reason for unemployment: Job loser/on layoff

- What was the main reason ... did not work in ...: Could not find work

- What was the main reason ... was not at work: Slack work/business conditions

\subsubsection{Lags}

Third, as both another identification strategy as well as exploration of timing, I use lagged unemployment of the husband as an explanatory variable. On the one hand, this allows for analyzing the timing of a response in wives' labor supply, but on the other hand, this reduces the possibility of endogeneity due to simultaneity, since a change in the husband's employment status happens before changes or decisions in the wife's hours worked and are therefore less likely to be determined by the wife's labor supply decision.

I use the option of matching CPS March supplements across two adjacent years, which allows me to lag unemployment of the husband by one year and lets me observe not only the level of hours worked by the wife but also the change in hours worked between the two years. It is reasonable to assume that the past unemployment status of the husband affects the wife's labor supply decision since it requires time to look for a job and find a job or increase hours in a current job, especially during recessions.

\subsubsection{Measures of labor underutilization}

The standard definition of unemployment classifies individuals as unemployed if they are without a job, but are available to work and have been actively looking for a job in the previous four weeks. Since this definition does not include discouraged workers and part-time workers that would

\footnotetext{
${ }^{12}$ The share of "involuntary unemployed" out of total unemployed is about $75 \%$ for the years $1988-2015$
} 
prefer to work full-time, and these two groups might have greater importance during recessions, I use the following three measures of labor underutilization following the Bureau of Labor Statistics.

- $U$-3: refers to the official classification of the unemployment rate.

- U-4: additionally includes discouraged workers.

- U-6: additionally includes all marginally attached workers plus all total employed part time for economic reasons.

\section{Results and Discussion}

\subsection{Estimation Results}

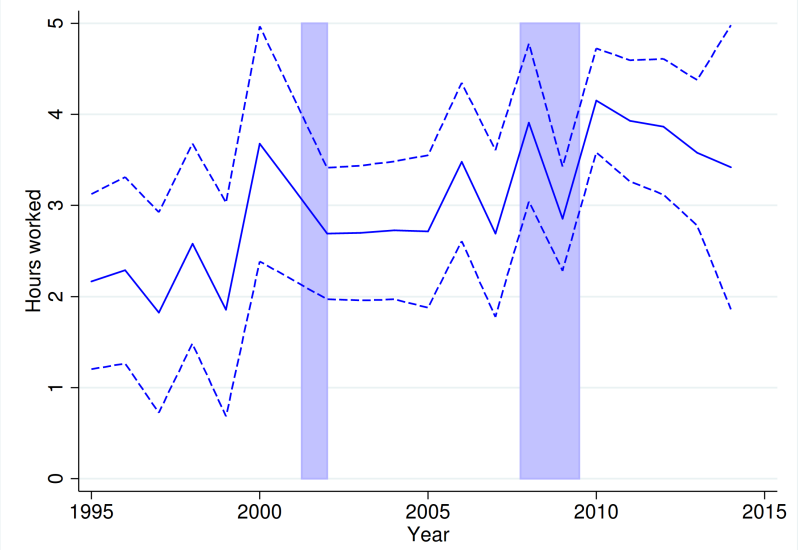

(a) All married women

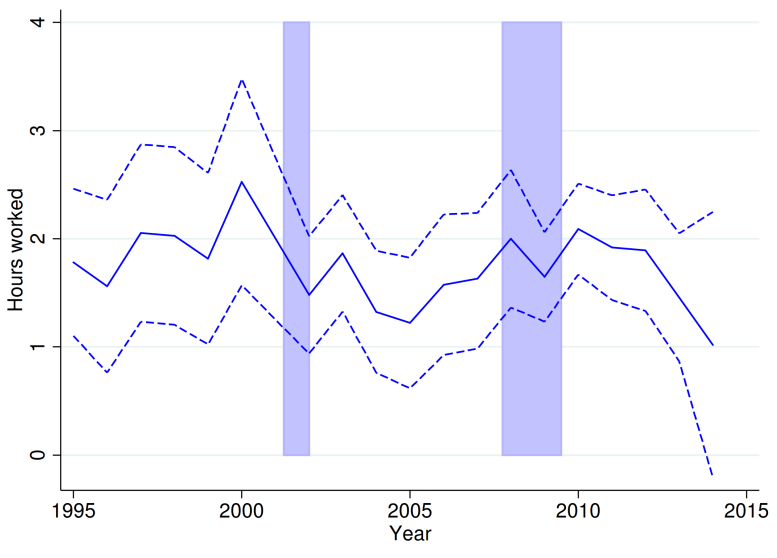

(b) Working married women

Figure 6: Hours worked in response to husband's unemployment

Figure 6 summarizes my main findings. The solid blue line plots the estimated coefficients on the husband's employment status for each year between 1995 and 2014 and shows the effect of husband's unemployment on hours worked by wives. The dashed lines indicate the 95 percent confidence interval. Both panels show that unemployment of the husband has a statistically significant positive effect on the number of weekly hours worked by his wife. Furthermore, the magnitude of hours worked in response to the husband's unemployment exhibits a countercyclical behavior. In both recessions, wives work on average 1.5 hours more in response to their husbands' unemployment than they do in normal times. The same is true when conditioning on working women, only the effect is smaller in magnitude. ${ }^{13}$

\footnotetext{
${ }^{13}$ Mankart and Oikonomou (2016b) find a similar procyclicality when estimating the added-worker effect for the years 1980 to 2012 . They show that the probablity of the wife entering the labor force when her husband becomes unemployed increased during the recession of 2007-2009.
} 
Table 11 shows my estimation results from estimating the effect of the husband's employment status on the wife's hours worked, using all three measures of unemployment, as well as involuntary unemployment, pooling the data across all years. Table 11 shows that the estimation results when

\begin{tabular}{|c|c|c|c|c|c|c|}
\hline & \multicolumn{3}{|c|}{ OLS Proxy } & \multicolumn{3}{|c|}{ OLS } \\
\hline \multicolumn{7}{|c|}{ Dependent variable: Wife's hours worked } \\
\hline & $(1)$ & $(2)$ & $(3)$ & $(4)$ & $(5)$ & (6) \\
\hline Husband unemployed U3 & $\begin{array}{l}3.331^{* * *} \\
(0.0933)\end{array}$ & & & $\begin{array}{l}3.067^{* * *} \\
(0.0802)\end{array}$ & & \\
\hline Husband unemployed U4 & & $\begin{array}{l}3.684^{* * *} \\
(0.0911)\end{array}$ & & & $\begin{array}{l}3.587^{* * *} \\
(0.0765)\end{array}$ & \\
\hline Husband unemployed U6 & & & $\begin{array}{l}2.739^{* * *} \\
(0.0642)\end{array}$ & & & $\begin{array}{l}3.272^{* * *} \\
(0.0781)\end{array}$ \\
\hline Wage wife & $\begin{array}{l}0.00175^{* *} \\
(0.000759)\end{array}$ & $\begin{array}{l}0.00174^{* *} \\
(0.000757)\end{array}$ & $\begin{array}{l}0.00169^{* *} \\
(0.000701)\end{array}$ & $\begin{array}{l}0.00177^{* *} \\
(0.000766)\end{array}$ & $\begin{array}{l}0.00169^{* *} \\
(0.000700)\end{array}$ & $\begin{array}{l}0.00169^{* *} \\
(0.000701)\end{array}$ \\
\hline Wage husband & $\begin{array}{l}-0.000676^{* * *} \\
(0.000142)\end{array}$ & $\begin{array}{l}-0.000676^{* * *} \\
(0.000142)\end{array}$ & $\begin{array}{l}-0.000677^{* * *} \\
(0.000142)\end{array}$ & $\begin{array}{l}-0.000678^{* * *} \\
(0.000142)\end{array}$ & $\begin{array}{l}-0.000677^{* * *} \\
(0.000142)\end{array}$ & $\begin{array}{l}-0.000677^{* * *} \\
(0.000142)\end{array}$ \\
\hline Children under 6 & $\begin{array}{l}-2.893^{* * *} \\
(0.0301)\end{array}$ & $\begin{array}{l}-2.891^{* * *} \\
(0.0301)\end{array}$ & $\begin{array}{l}-2.894^{* * *} \\
(0.0300)\end{array}$ & $\begin{array}{l}-2.896^{* * *} \\
(0.0300)\end{array}$ & $\begin{array}{l}-2.890^{* * *} \\
(0.0300)\end{array}$ & $\begin{array}{l}-2.893^{* * *} \\
(0.0300)\end{array}$ \\
\hline Children under 18 & $\begin{array}{l}-2.059^{* * *} \\
(0.0163)\end{array}$ & $\begin{array}{l}-2.059 * * * \\
(0.0163)\end{array}$ & $\begin{array}{l}-2.045^{* * *} \\
(0.0162)\end{array}$ & $\begin{array}{l}-2.047^{* * *} \\
(0.0162)\end{array}$ & $\begin{array}{l}-2.043^{* * *} \\
(0.0162)\end{array}$ & $\begin{array}{l}-2.044^{* * *} \\
(0.0162)\end{array}$ \\
\hline Age wife & $\begin{array}{l}0.216^{* * * *} \\
(0.0157)\end{array}$ & $\begin{array}{l}0.217^{* * * *} \\
(0.0157)\end{array}$ & $\begin{array}{l}0.216^{* * * *} \\
(0.0156)\end{array}$ & $\begin{array}{l}0.217^{* * * *} \\
(0.0156)\end{array}$ & $\begin{array}{l}0.219^{* * * *} \\
(0.0156)\end{array}$ & $\begin{array}{l}0.219^{* * * *} \\
(0.0156)\end{array}$ \\
\hline Age wife squared & $\begin{array}{l}-0.00555^{* * *} \\
(0.000184)\end{array}$ & $\begin{array}{l}-0.00555^{* * *} \\
(0.000184)\end{array}$ & $\begin{array}{l}-0.00555^{* * *} \\
(0.000183)\end{array}$ & $\begin{array}{l}-0.00556^{* * *} \\
(0.000183)\end{array}$ & $\begin{array}{l}-0.00557^{* * *} \\
(0.000183)\end{array}$ & $\begin{array}{l}-0.00557^{* * *} \\
(0.000183)\end{array}$ \\
\hline Education wife & $\begin{array}{l}1.553^{* * *} \\
(0.0149)\end{array}$ & $\begin{array}{l}1.553^{* * *} \\
(0.0149)\end{array}$ & $\begin{array}{l}1.548^{* * * *} \\
(0.0148)\end{array}$ & $\begin{array}{l}1.552^{* * * *} \\
(0.0149)\end{array}$ & $\begin{array}{l}1.551^{* * *} \\
(0.0148)\end{array}$ & $\begin{array}{l}1.552^{* * *} \\
(0.0148)\end{array}$ \\
\hline Education husband & $\begin{array}{l}-1.639^{* * *} \\
(0.0138)\end{array}$ & $\begin{array}{l}-1.636^{* * *} \\
(0.0138)\end{array}$ & $\begin{array}{l}-1.615^{* * *} \\
(0.0137)\end{array}$ & $\begin{array}{l}-1.627^{* * *} \\
(0.0137)\end{array}$ & $\begin{array}{l}-1.620^{* * *} \\
(0.0137)\end{array}$ & $\begin{array}{l}-1.623^{* * *} \\
(0.0137)\end{array}$ \\
\hline Income percentile & $\begin{array}{l}1.022^{* * *} \\
(0.00530)\end{array}$ & $\begin{array}{l}1.022^{* * *} \\
(0.00529)\end{array}$ & $\begin{array}{l}1.023^{* * *} \\
(0.00527)\end{array}$ & $\begin{array}{l}1.017^{* * *} \\
(0.00525)\end{array}$ & $\begin{array}{l}1.016^{* * *} \\
(0.00524)\end{array}$ & $\begin{array}{l}1.016^{* * *} \\
(0.00524)\end{array}$ \\
\hline Total family earnings & $\begin{array}{l}-6.46 \mathrm{e}-06^{* * *} \\
(3.20 \mathrm{e}-07)\end{array}$ & $\begin{array}{l}-6.47 \mathrm{e}-06^{* * *} \\
(3.20 \mathrm{e}-07)\end{array}$ & $\begin{array}{l}-6.51 \mathrm{e}-06^{* * *} \\
(3.17 \mathrm{e}-07)\end{array}$ & $\begin{array}{l}-6.37 \mathrm{e}-06^{* * *} \\
(3.19 \mathrm{e}-07)\end{array}$ & $\begin{array}{l}-6.38 \mathrm{e}-06^{* * *} \\
(3.17 \mathrm{e}-07)\end{array}$ & $\begin{array}{l}-6.37 \mathrm{e}-06^{* * *} \\
(3.17 \mathrm{e}-07)\end{array}$ \\
\hline Recession dummy & $\begin{array}{l}0.392^{* * * *} \\
(0.0405)\end{array}$ & $\begin{array}{l}0.389^{* * *} \\
(0.0405)\end{array}$ & $\begin{array}{l}0.375^{* * *} \\
(0.0402)\end{array}$ & $\begin{array}{l}0.385^{* * *} \\
(0.0403)\end{array}$ & $\begin{array}{l}0.377^{* * *} \\
(0.0402)\end{array}$ & $\begin{array}{l}0.381^{* * *} \\
(0.0402)\end{array}$ \\
\hline Constant & $\begin{array}{l}21.90^{* * * *} \\
(0.326)\end{array}$ & $\begin{array}{l}21.87^{* * * *} \\
(0.326)\end{array}$ & $\begin{array}{l}21.76^{* * * *} \\
(0.324)\end{array}$ & $\begin{array}{l}21.87^{* * * *} \\
(0.324)\end{array}$ & $\begin{array}{l}21.80^{* * *} \\
(0.324)\end{array}$ & $\begin{array}{l}21.84^{* * *} \\
(0.324)\end{array}$ \\
\hline Observations & $1,103,946$ & $1,104,566$ & $1,118,300$ & $1,114,571$ & $1,117,944$ & $1,117,070$ \\
\hline
\end{tabular}

Table 11: Regression results

using all households with unemployed husbands and the estimation results only using households with husbands that are involuntarily unemployed are almost identical. Focusing on the standard definition of unemployment, columns (1) and (4) show that unemployment of the husband ${ }^{14}$ has a positive impact on hours worked of the wife. On average, the wife works 3.5 hours more a week if her husband is unemployed. The other columns show the effect of different unemployment definitions

\footnotetext{
${ }^{14}$ The dummy variable unemp $_{i}^{h}$ is coded $=1$ if the husband if unemployed and $=0$ if he is employed.
} 
on hours worked and the effect is statistically significant and positive with respect to all three different measures. The coefficients of the other explanatory variables are mostly as expected, for example, wife's education has a significant positive effect and the number of own children present in the household has a significant negative effect. Furthermore, I included a dummy in the regression equation, which indicates whether the observation was during a recession period. Table 11 shows that the recession dummy is positive and statistically significant, indicating that being in a recession, on average, has a positive impact on hours worked by married women.

\begin{tabular}{|c|c|c|c|c|c|}
\hline \multirow[t]{2}{*}{ Dependent variable: Wife's hours worked } & \multicolumn{4}{|c|}{ Level } & \multirow{2}{*}{$\frac{\text { Change }}{(5)}$} \\
\hline & $(1)$ & $(2)$ & $(3)$ & $(4)$ & \\
\hline Husband unemployed U3 one-year lag & $\begin{array}{l}2.087^{* * *} \\
(0.261)\end{array}$ & - & - & $\begin{array}{l}2.915^{* * *} \\
(0.323)\end{array}$ & $\begin{array}{l}0.689^{* * *} \\
(0.264)\end{array}$ \\
\hline Husband unemployed U4 one-year lag & - & $\begin{array}{l}2.120^{* * * *} \\
(0.247)\end{array}$ & - & - & - \\
\hline Husband unemployed U6 one-year lag & - & - & $\begin{array}{l}1.853^{* * *} \\
(0.197)\end{array}$ & - & - \\
\hline Change in employment status husband & - & - & - & $\begin{array}{l}1.206^{* * *} \\
(0.272)\end{array}$ & $\begin{array}{l}0.590^{* * *} \\
(0.218)\end{array}$ \\
\hline Wage wife & $\begin{array}{l}0.0002^{* * *} \\
(5.13 \mathrm{e}-06)\end{array}$ & $\begin{array}{l}0.0002^{* * *} \\
(5.11 \mathrm{e}-08)\end{array}$ & $\begin{array}{l}0.0002 * * * \\
(5.05 \mathrm{e}-06)\end{array}$ & $\begin{array}{l}0.0002^{* * *} \\
(5.12 \mathrm{e}-06)\end{array}$ & $\begin{array}{l}-0.00002^{* * *} \\
(1.89 \mathrm{e}-06)\end{array}$ \\
\hline Wage husband & $\begin{array}{l}-0.00001^{* * *} \\
(2.58 \mathrm{e}-06)\end{array}$ & $\begin{array}{l}-0.00001^{* * *} \\
(2.58 \mathrm{e}-06)\end{array}$ & $\begin{array}{l}-2.77 \mathrm{e}-06 \\
(2.59 \mathrm{e}-06)\end{array}$ & $\begin{array}{l}-0.00001^{* * *} \\
(2.58 \mathrm{e}-06)\end{array}$ & $\begin{array}{l}-1.23 \mathrm{e}-06 \\
(1.63 \mathrm{e}-06)\end{array}$ \\
\hline Children under 6 & $\begin{array}{l}-3.244^{* * *} \\
(0.093)\end{array}$ & $\begin{array}{l}-3.238^{* * *} \\
(0.093)\end{array}$ & $\begin{array}{l}-3.197^{* * *} \\
(0.092)\end{array}$ & $\begin{array}{l}-3.244^{* * *} \\
(0.093)\end{array}$ & $\begin{array}{l}-0.691^{* * *} \\
(0.076)\end{array}$ \\
\hline Children under 18 & $\begin{array}{l}-1.557^{* * *} \\
(0.053)\end{array}$ & $\begin{array}{l}-1.556^{* * *} \\
(0.052)\end{array}$ & $\begin{array}{l}-1.534^{* * *} \\
(0.052)\end{array}$ & $\begin{array}{l}-1.558^{* * *} \\
(0.053)\end{array}$ & $\begin{array}{l}0.427^{* * *} \\
(0.042)\end{array}$ \\
\hline Age wife & $\begin{array}{l}0.398^{* * *} \\
(0.036)\end{array}$ & $\begin{array}{l}0.403^{* * *} \\
(0.036)\end{array}$ & $\begin{array}{l}0.459^{* * *} \\
(0.035)\end{array}$ & $\begin{array}{l}0.398^{* * *} \\
(0.036)\end{array}$ & $\begin{array}{l}-0.026 \\
(0.028)\end{array}$ \\
\hline Age wife squared & $\begin{array}{l}-0.007^{* * *} \\
(0.0004)\end{array}$ & $\begin{array}{l}-0.007^{* * *} \\
(0.0004)\end{array}$ & $\begin{array}{l}-0.008^{* * *} \\
(0.0004)\end{array}$ & $\begin{array}{l}-0.007^{* * *} \\
(0.0004)\end{array}$ & $\begin{array}{l}0.0002 \\
(0.0003)\end{array}$ \\
\hline Education wife & $\begin{array}{l}0.459^{* * *} \\
(0.021)\end{array}$ & $\begin{array}{l}0.457^{* * * *} \\
(0.019)\end{array}$ & $\begin{array}{l}0.426^{* * *} \\
(0.019)\end{array}$ & $\begin{array}{l}0.459^{* * * *} \\
(0.019)\end{array}$ & $\begin{array}{l}0.034^{* *} \\
(0.015)\end{array}$ \\
\hline Education husband & $\begin{array}{l}-0.548^{* * *} \\
(0.023)\end{array}$ & $\begin{array}{l}-0.547^{* * *} \\
(0.023)\end{array}$ & $\begin{array}{l}-0.543^{* * *} \\
(0.023)\end{array}$ & $\begin{array}{l}-0.545^{* * *} \\
(0.023)\end{array}$ & $\begin{array}{l}0.172^{* * *} \\
(0.018)\end{array}$ \\
\hline Income percentile & $\begin{array}{l}0.939^{* * *} \\
(0.027)\end{array}$ & $\begin{array}{l}0.938^{* * *} \\
(0.027)\end{array}$ & $\begin{array}{l}0.993^{* * *} \\
(0.026)\end{array}$ & $\begin{array}{l}0.942^{* * *} \\
(0.027)\end{array}$ & $\begin{array}{l}-0.157^{* * *} \\
(0.014)\end{array}$ \\
\hline Total family earnings & $\begin{array}{l}-0.00005^{* * *} \\
(2.63 \mathrm{e}-06)\end{array}$ & $\begin{array}{l}-0.00005^{* * *} \\
(2.64 \mathrm{e}-06)\end{array}$ & $\begin{array}{l}-0.00006^{* * *} \\
(2.67 \mathrm{e}-06)\end{array}$ & $\begin{array}{l}-0.00005^{* * *} \\
(2.63 \mathrm{e}-06)\end{array}$ & $\begin{array}{l}4.85 \mathrm{e}-06^{* * *} \\
(1.57 \mathrm{e}-06)\end{array}$ \\
\hline Recession dummy & $\begin{array}{l}0.457^{* * *} \\
(0.105)\end{array}$ & $\begin{array}{l}0.459^{* * *} \\
(0.105)\end{array}$ & $\begin{array}{l}0.458^{* * *} \\
(0.103)\end{array}$ & $\begin{array}{l}0.435^{* * *} \\
(0.105)\end{array}$ & $\begin{array}{l}0.044 \\
(0.083)\end{array}$ \\
\hline Constant & $\begin{array}{l}17.051^{* * *} \\
(0.918)\end{array}$ & $\begin{array}{l}17.019 * * * \\
(0.916)\end{array}$ & $\begin{array}{l}16.340^{* * *} \\
(0.895)\end{array}$ & $\begin{array}{l}16.866^{* * *} \\
(0.918)\end{array}$ & $\begin{array}{l}-5.927^{* * *} \\
(0.699)\end{array}$ \\
\hline Observations & 109,110 & 109,523 & 113,213 & 109,110 & 109,110 \\
\hline
\end{tabular}

Table 12: Regression results using lagged unemployment status of husband as explanatory variable 
Table 12 shows the results from estimating the effect of the husband's (un)employment status from one year ago on the current hours worked by his wife. Overall, the results are similar to the estimation results in table 11. Unemployment of the husband a year ago has a statistically significant positive effect on hours worked of the wife. The effect is lower than the effect of current unemployment on hours worked, for each category by about one hour worked per week. On the one hand, one might expect that hours worked of the wife react delayed to her husband, which explains that the effect is positive. On the other hand, one year is a long time period and in columns (1), (2), and (3) I am not controlling for whether the husband is currently employed, unemployed, or not in the labor force, which might explain that the effect is positive but smaller in magnitude compared to the effect of current unemployment. Similar to my results estimating the effect of the husband's current employment status on the wife's hours worked, being in a recession has a statistically significant positive effect on hours worked of the wife.

Column (4) additionally controls for the change in the husband's employment status within the year. Thus, I estimate the effect of unemployment last year as well as the effect of a change from employment to unemployment and vice versa on current hours worked of the wife. Table 12 column (4) shows that a change from employment to unemployment by the husband within the observed year has a statistically significant positive effect on hours worked by the wife.

Column (5) shows the effect of past employment status, change in unemployment, and personal and household characteristics on a change in hours worked of the wife between two subsequent years. Both past unemployment by the husband as well as a change from employment to unemployment by the husband have a statistically significant and positive effect on the change in hours worked, indicating that married women, on average, increase their hours worked when their husband is unemployed or becomes unemployed.

\subsection{Extensions and Robustness}

The following section presents results from robustness checks. Table 13 illustrates the estimation results when I restrict the number of households by only looking at those where the wife indicates that she works at least one hour in a given week. Even when considering the intensive margin only, unemployment of the husband is associated with about two hours more per week on average for the wife across the different unemployment categories. Thus, while the added-worker effect is important, spousal insurance also works with respect to the intensive margin.

Table 14 shows the estimation results when I additionally include occupation and industry 


\begin{tabular}{|c|c|c|c|c|c|c|}
\hline & \multicolumn{3}{|c|}{ OLS Proxy } & \multicolumn{3}{|c|}{ OLS } \\
\hline \multicolumn{7}{|c|}{ Dependent variable: Wife's hours worked } \\
\hline & $(1)$ & $(2)$ & $(3)$ & $(4)$ & $(5)$ & $(6)$ \\
\hline Husband unemployed U3 & $\begin{array}{l}1.995^{* * *} \\
(0.065)\end{array}$ & - & - & $\begin{array}{l}1.915^{* * *} \\
(0.055)\end{array}$ & $\begin{array}{l}- \\
-\end{array}$ & - \\
\hline Husband unemployed U4 & - & $\begin{array}{l}2.045^{* * *} \\
(0.064)\end{array}$ & - & - & $\begin{array}{l}2.096^{* * *} \\
(0.053)\end{array}$ & - \\
\hline Husband unemployed U6 & - & - & $\begin{array}{l}1.324^{* * *} \\
(0.052)\end{array}$ & - & - & $\begin{array}{l}2.009^{* * *} \\
(0.054)\end{array}$ \\
\hline Wage wife & $\begin{array}{l}0.001^{* *} \\
(0.0002)\end{array}$ & $\begin{array}{l}0.001^{* *} \\
(0.0002)\end{array}$ & $\begin{array}{l}0.001^{* *} \\
(0.0002)\end{array}$ & $\begin{array}{l}0.001^{* *} \\
(0.0002)\end{array}$ & $\begin{array}{l}0.001 * * * \\
(0.0002)\end{array}$ & $\begin{array}{l}0.001^{* * *} \\
(0.0002)\end{array}$ \\
\hline Wage husband & $\begin{array}{l}-0.001^{* * *} \\
(0.0001)\end{array}$ & $\begin{array}{l}-0.001 * * * \\
(0.0002)\end{array}$ & $\begin{array}{l}-0.001 * * * \\
(0.0002)\end{array}$ & $\begin{array}{l}-0.001^{* * *} \\
(0.0001)\end{array}$ & $\begin{array}{l}-0.001^{* * *} \\
(0.0002)\end{array}$ & $\begin{array}{l}-0.001^{* * *} \\
(0.0002)\end{array}$ \\
\hline Children under 6 & $\begin{array}{l}-1.111^{* * *} \\
(0.024)\end{array}$ & $\begin{array}{l}1.111^{* * *} \\
(0.024)\end{array}$ & $\begin{array}{l}-1.112^{* * *} \\
(0.024)\end{array}$ & $\begin{array}{l}-1.100^{* * *} \\
(0.024)\end{array}$ & $\begin{array}{l}-1.096^{* * *} \\
(0.024)\end{array}$ & $\begin{array}{l}-1.098^{* * *} \\
(0.024)\end{array}$ \\
\hline Children under 18 & $\begin{array}{l}-1.592^{* * *} \\
(0.013)\end{array}$ & $\begin{array}{l}-1.592^{* * * *} \\
(0.013)\end{array}$ & $\begin{array}{l}-1.592^{* * *} \\
(0.013)\end{array}$ & $\begin{array}{l}-1.583^{* * *} \\
(0.013)\end{array}$ & $\begin{array}{l}-1.579^{* * *} \\
(0.013)\end{array}$ & $\begin{array}{l}-1.580^{* * * *} \\
(0.013)\end{array}$ \\
\hline Age wife & $\begin{array}{l}0.319^{* * *} \\
(0.013)\end{array}$ & $\begin{array}{l}0.319^{* * *} \\
(0.013)\end{array}$ & $\begin{array}{l}0.319^{* * *} \\
(0.013)\end{array}$ & $\begin{array}{l}0.320^{* * *} \\
(0.013)\end{array}$ & $\begin{array}{l}0.319^{* * *} \\
(0.013)\end{array}$ & $\begin{array}{l}0.320^{* * *} \\
(0.013)\end{array}$ \\
\hline Age wife squared & $\begin{array}{l}-0.005^{* * *} \\
(0.0001)\end{array}$ & $\begin{array}{l}-0.005^{* * *} \\
(0.0001)\end{array}$ & $\begin{array}{l}-0.005^{* * *} \\
(0.0001)\end{array}$ & $\begin{array}{l}-0.005^{* * *} \\
(0.0001)\end{array}$ & $\begin{array}{l}-0.005^{* * *} \\
(0.0001)\end{array}$ & $\begin{array}{l}-0.005^{* * *} \\
(0.0001)\end{array}$ \\
\hline Education wife & $\begin{array}{l}1.229 \\
(0.018)\end{array}$ & $\begin{array}{l}1.228^{* * *} \\
(0.018)\end{array}$ & $\begin{array}{l}1.227^{* * *} \\
(0.018)\end{array}$ & $\begin{array}{l}1.225^{* * *} \\
(0.018)\end{array}$ & $\begin{array}{l}1.224^{* * *} \\
(0.018)\end{array}$ & $\begin{array}{l}1.226^{* * *} \\
(0.018)\end{array}$ \\
\hline Education husband & $\begin{array}{l}-1.264^{* * *} \\
(0.012)\end{array}$ & $\begin{array}{l}-1.264^{* * *} \\
(0.018)\end{array}$ & $\begin{array}{l}-1.264^{* * *} \\
(0.018)\end{array}$ & $\begin{array}{l}-1.260^{* * *} \\
(0.018)\end{array}$ & $\begin{array}{l}-1.256^{* * *} \\
(0.018)\end{array}$ & $\begin{array}{l}-1.258^{* * *} \\
(0.018)\end{array}$ \\
\hline Income percentile & $\begin{array}{l}0.385^{* * *} \\
(0.004)\end{array}$ & $\begin{array}{l}0.386^{* * *} \\
(0.004)\end{array}$ & $\begin{array}{l}0.387^{* * *} \\
(0.004)\end{array}$ & $\begin{array}{l}0.382^{* * *} \\
(0.004)\end{array}$ & $\begin{array}{l}0.383^{* * *} \\
(0.004)\end{array}$ & $\begin{array}{l}0.382^{* * *} \\
(0.004)\end{array}$ \\
\hline Total family earnings & $\begin{array}{l}4.43 \mathrm{e}-06^{* * *} \\
(2.60 \mathrm{e}-07)\end{array}$ & $\begin{array}{l}4.42 \mathrm{e}-06^{* * *} \\
(2.60 \mathrm{e}-07)\end{array}$ & $\begin{array}{l}4.40 \mathrm{e}-06 * * * \\
(2.60 \mathrm{e}-07)\end{array}$ & $\begin{array}{l}4.51 \mathrm{e}-06^{* * *} \\
(2.59 \mathrm{e}-07)\end{array}$ & $\begin{array}{l}4.48 \mathrm{e}-06^{* * *} \\
(2.59 \mathrm{e}-07)\end{array}$ & $\begin{array}{l}4.50 \mathrm{e}-06^{* * *} \\
(2.59 \mathrm{e}-07)\end{array}$ \\
\hline Recession dummy & $\begin{array}{l}0.225^{* * *} \\
(0.030)\end{array}$ & $\begin{array}{l}0.225^{* * *} \\
(0.030)\end{array}$ & $\begin{array}{l}0.224^{* * *} \\
(0.030)\end{array}$ & $\begin{array}{l}0.227^{* * *} \\
(0.030)\end{array}$ & $\begin{array}{l}0.226^{* * *} \\
(0.030)\end{array}$ & $\begin{array}{l}0.225^{* * *} \\
(0.030)\end{array}$ \\
\hline Constant & $\begin{array}{l}29.813^{* * *} \\
(0.174) \\
\end{array}$ & $\begin{array}{l}29.808^{* * *} \\
(0.174) \\
\end{array}$ & $\begin{array}{l}29.794^{* * *} \\
(0.174) \\
\end{array}$ & $\begin{array}{l}29.772^{* * * *} \\
(0.173) \\
\end{array}$ & $\begin{array}{l}29.703^{* * *} \\
(0.172) \\
\end{array}$ & $\begin{array}{l}29.732^{* * *} \\
(0.173) \\
\end{array}$ \\
\hline Observations & $1,052,071$ & $1,052,071$ & $1,052,071$ & $1,062,880$ & $1,066,585$ & $1,065,547$ \\
\hline
\end{tabular}

Robust standard errors in parentheses; ${ }^{*} \mathrm{p}$-value $<0.1,{ }^{* *} \mathrm{p}$-value $<0.05,{ }^{* * *} \mathrm{p}$-value $<0.01$

Table 13: Regression results from OLS regression using different unemployment classifications: working women only

dummies for married women into the regression. Since the previous results are similar with respect to the choice of the unemployment category, I only use the standard classification of unemployment, but distinguish between working married women and all married women. However, since the CPS adopted a different industry and occupation classification scheme in 2003, I have to restrict my sample on observations from 2003 on. The inclusion of occupation and industry dummies leads to a statistically significant positive effect of husband's unemployment on the wife's hours worked, similar in magnitude to the previous results. Married women work about 3.5 to 4 hours more on 


\begin{tabular}{|c|c|c|c|c|c|c|}
\hline \multicolumn{7}{|c|}{ Dependent variable: Wife's hours worked } \\
\hline & $(1)$ & $(2)$ & $(3)$ & $(4)$ & $(5)$ & $(6)$ \\
\hline Husband unemployed U3 & $\begin{array}{l}3.694^{* * *} \\
(0.102)\end{array}$ & $\begin{array}{l}1.787^{* * *} \\
(0.076)\end{array}$ & $\begin{array}{l}3.654^{* * *} \\
(0.102)\end{array}$ & $\begin{array}{l}1.756^{* * *} \\
(0.076)\end{array}$ & $\begin{array}{l}3.696^{* * *} \\
(0.102)\end{array}$ & $\begin{array}{l}1.777^{* * *} \\
(0.076)\end{array}$ \\
\hline Wage wife & $\begin{array}{l}0.001^{* *} \\
(0.0004)\end{array}$ & $\begin{array}{l}0.0004^{* *} \\
(0.0001)\end{array}$ & $\begin{array}{l}0.001^{* *} \\
(0.0005)\end{array}$ & $\begin{array}{l}0.0004^{* *} \\
(0.0001)\end{array}$ & $\begin{array}{l}0.001^{* *} \\
(0.0005)\end{array}$ & $\begin{array}{l}0.0004^{* *} \\
(0.0001)\end{array}$ \\
\hline Wage husband & $\begin{array}{l}-0.001^{* * *} \\
(0.0001)\end{array}$ & $\begin{array}{l}-0.001^{* * *} \\
(0.0001)\end{array}$ & $\begin{array}{l}-0.001 * * * \\
(0.0001)\end{array}$ & $\begin{array}{l}-0.001 * * * \\
(0.0001)\end{array}$ & $\begin{array}{l}-0.001 * * * \\
(0.0001)\end{array}$ & $\begin{array}{l}-0.001 * * * \\
(0.0001)\end{array}$ \\
\hline Children under 6 & $\begin{array}{l}-2.289^{* * *} \\
(0.038)\end{array}$ & $\begin{array}{l}-0.815^{* * *} \\
(0.032)\end{array}$ & $\begin{array}{l}-2.279^{* * *} \\
(0.038)\end{array}$ & $\begin{array}{l}-0.814^{* * *} \\
(0.032)\end{array}$ & $\begin{array}{l}-2.234^{* * *} \\
(0.038)\end{array}$ & $\begin{array}{l}-0.814^{* * *} \\
(0.032)\end{array}$ \\
\hline Children under 18 & $\begin{array}{l}-2.204^{* * *} \\
(0.021)\end{array}$ & $\begin{array}{l}-1.563^{* * *} \\
(0.017)\end{array}$ & $\begin{array}{l}-2.166^{* * *} \\
(0.021)\end{array}$ & $\begin{array}{l}-1.558^{* * *} \\
(0.017)\end{array}$ & $\begin{array}{l}-2.175^{* * *} \\
(0.021)\end{array}$ & $\begin{array}{l}-1.560^{* * *} \\
(0.017)\end{array}$ \\
\hline Age wife & $\begin{array}{l}0.603^{* * *} \\
(0.013)\end{array}$ & $\begin{array}{l}0.243^{* * *} \\
(0.011)\end{array}$ & $\begin{array}{l}0.597^{* * *} \\
(0.013)\end{array}$ & $\begin{array}{l}0.241^{* * *} \\
(0.011)\end{array}$ & $\begin{array}{l}0.596^{* * *} \\
(0.013)\end{array}$ & $\begin{array}{l}0.237^{* * *} \\
(0.011)\end{array}$ \\
\hline Age wife squared & $\begin{array}{l}-0.010^{* * *} \\
(0.0001)\end{array}$ & $\begin{array}{l}-0.004^{* * *} \\
(0.0001)\end{array}$ & $\begin{array}{l}-0.001 * * * \\
(0.0001)\end{array}$ & $\begin{array}{l}-0.004^{* * *} \\
(0.0001)\end{array}$ & $\begin{array}{l}-0.001^{* * *} \\
(0.0001)\end{array}$ & $\begin{array}{l}-0.004^{* * *} \\
(0.0001)\end{array}$ \\
\hline Education wife & $\begin{array}{l}2.175^{* * *} \\
(0.032)\end{array}$ & $\begin{array}{l}0.753^{* * *} \\
(0.025)\end{array}$ & $\begin{array}{l}2.573^{* * *} \\
(0.032)\end{array}$ & $\begin{array}{l}0.831^{* * *} \\
(0.025)\end{array}$ & $\begin{array}{l}2.409^{* * *} \\
(0.032)\end{array}$ & $\begin{array}{l}0.783^{* * *} \\
(0.250)\end{array}$ \\
\hline Education husband & $\begin{array}{l}-3.061^{* * *} \\
(0.030)\end{array}$ & $\begin{array}{l}-1.683^{* * *} \\
(0.023)\end{array}$ & $\begin{array}{l}-2.882^{* * *} \\
(0.030)\end{array}$ & $\begin{array}{l}-1.612^{* * *} \\
(0.024)\end{array}$ & $\begin{array}{l}-2.876^{* * *} \\
(0.030)\end{array}$ & $\begin{array}{l}-1.627^{* * *} \\
(0.024)\end{array}$ \\
\hline Income percentile & $\begin{array}{l}1.228^{* * *} \\
(0.007)\end{array}$ & $\begin{array}{l}0.503^{* * *} \\
(0.006)\end{array}$ & $\begin{array}{l}1.213^{* * *} \\
(0.007)\end{array}$ & $\begin{array}{l}0.504^{* * *} \\
(0.006)\end{array}$ & $\begin{array}{l}1.236^{* * *} \\
(0.007)\end{array}$ & $\begin{array}{l}0.500^{* * *} \\
(0.006)\end{array}$ \\
\hline Total family earnings & $\begin{array}{l}-1.06 \mathrm{e}-05^{* * *} \\
(3.84 \mathrm{e}-07)\end{array}$ & $\begin{array}{l}1.54 \mathrm{e}-06^{* * *} \\
(2.94 \mathrm{e}-07)\end{array}$ & $\begin{array}{l}-1.03 \mathrm{e}-05^{* * *} \\
(3.82 \mathrm{e}-07)\end{array}$ & $\begin{array}{l}1.26 \mathrm{e}-06^{* * *} \\
(2.95 \mathrm{e}-07)\end{array}$ & $\begin{array}{l}-9.79 \mathrm{e}-06^{* * *} \\
(3.81 \mathrm{e}-07)\end{array}$ & $\begin{array}{l}1.53 \mathrm{e}-06^{* * *} \\
(2.95 \mathrm{e}-07)\end{array}$ \\
\hline Recession dummy & $\begin{array}{l}0.430^{* * *} \\
(0.050)\end{array}$ & $\begin{array}{l}0.175^{* * *} \\
(0.039)\end{array}$ & $\begin{array}{l}0.423^{* * *} \\
(0.050)\end{array}$ & $\begin{array}{l}0.174^{* * *} \\
(0.039)\end{array}$ & $\begin{array}{l}0.436^{* * *} \\
(0.050)\end{array}$ & $\begin{array}{l}0.177^{* * *} \\
(0.039)\end{array}$ \\
\hline Industry dummies & Yes & Yes & No & No & Yes & Yes \\
\hline Occupation dummies & No & No & Yes & Yes & Yes & Yes \\
\hline Married women & All & Working & All & Working & All & Working \\
\hline Constant & $\begin{array}{l}20.60^{* * *} \\
(4.108)\end{array}$ & $\begin{array}{l}33.94^{* * *} \\
(2.632) \\
\end{array}$ & $\begin{array}{l}19.703^{* * *} \\
(4.084)\end{array}$ & $\begin{array}{l}29.140 \\
(167.79)\end{array}$ & $\begin{array}{l}19.777^{* * *} \\
(4.010)\end{array}$ & $\begin{array}{l}26.953 \\
(444.351)\end{array}$ \\
\hline Observations & 663,420 & 566,181 & 663,420 & 566,181 & 663,420 & 566,181 \\
\hline
\end{tabular}

Table 14: Regression results including industry and occupation dummies

average in a given week if their husband is unemployed. Already working women work about 2 hours more in a given week if their husband is unemployed.

\subsection{Discussion and Future Research}

The section on aggregate and cyclical volatility provides strong empirical evidence about the differences in volatility of hours worked by married women relative to married men, single men, and single women. Married women experience significantly lower cyclical volatility, i.e. volatility in 
hours worked correlated with fluctuations in the unemployment rate, than married men and single individuals. The previous section shows that unemployment by the husband has a positive effect on hours worked by the wife and furthermore, being in a recession also has a statistically significant positive impact on hours worked. Similarly, a change from employment to unemployment by the husband is associated with an increase in hours worked of the wife. Thus, while the data on aggregate hours worked finds that married women experience low volatility, micro data provides evidence of the existence of spousal insurance, i.e. married women, on average, work more hours when their husband is unemployed and increase their hours when their husband becomes unemployed.

\section{Conclusion}

This paper documents empirically that married women experience significantly lower aggregate volatility in hours worked than married men, single men, and single women, and provides evidence that the lower cyclicality of hours worked for married women can be explained by spousal insurance.

In particular, this paper finds, that married individuals are characterized by lower total and cyclical volatility than single individuals. Moreover, married women not only have the lowest cyclical volatility relative to married men, single men, and single women, but for married women the share of total volatility attributed to cyclical volatility is smallest. I argue that these facts regarding aggregate volatility can be explained by the behavior of married women who increase their hours worked in recessionary phases when their husbands are more likely to face negative wage and labor supply shocks and thus, counteract the procyclical behavior of other married women, leading to the apparent low cyclicality when aggregating the two groups. Furthermore, the paper investigates whether timing in hours worked matters for the different groups. An extension of cyclical volatility which captures volatility in hours worked with respect to past unemployment rate fluctuations finds that cyclical volatility of hours worked for married women is higher when relating it to changes in the lagged unemployment rate. Using micro data, I substantiate this finding regarding timing, because estimations show that married women, on average, increase their hours worked in response to unemployment by their husband in the past year as well as a change in the labor market status from employment to unemployment by their husband. Lastly, an analysis of transition probabilities between employment, unemployment and not-in-the-labor force shows that married women do not differ from married men and single individuals in their probability of entering the labor force during a recession, but are more likely to stay unemployed and therefore, 
less likely to become unemployed or leave the labor force during recessions than married men and singles. 


\section{References}

Attanasio, O., H. Low, and V. Sanchez-Marcos (2005): "Female Labor Supply as Insurance against Idiosyncratic Risk," Journal of the European Economic Association, 3 no. 2/3, 755-764.

(2008): "Explaining Changes in Female Labor Supply in a Life-Cycle Model," American Economic Review, 98(4), 1517-1552.

Baxter, M., And R. G. King (1999): "Measuring Business Cycles: Approximate Band-Pass Filters for Economic Time Series," Review of Economics and Statistics, 81(4), 575-593.

Blundell, R., A. Bozio, and G. Laroque (2011): "Labor Supply Responses and the Extensive Margin: The US, UK, and France," American Economic Review, 101(3), 482-486.

Blundell, R., P.-A. Chiappori, T. Magnac, and C. Meghir (2007): "Collective Labour Supply: Heterogeneity and Non-Participation," The Review of Economic Studies, 74, No.2, 417445.

Blundell, R., M. Graeber, and M. Mogstad (2015): "Labor Income Dynamics and the Insurance from Taxes, Transfers, and the Family," Journal of Public Economics, 127, 58-73.

Blundell, R., L. Pistaferri, and I. Saporta-Eksten (2016a): "Children, Time Allocation, and Consumption Insurance," Institute for Fiscal Studies Working Paper.

(2016b): "Consumption Inequality and Family Labor Supply," American Economic Review, 106(2), 387-435.

Cerina, F., A. Moro, and M. Rendall (2016): "The Role of Gender in Employment Polarization," Working Paper.

Choi, S., and A. Valladares-Esteban (2017): "The marriage unemployment gap," The B.E. Journal of Macroeconomics, forthcoming.

Doepke, M., And M. Tertilt (2016): "Families in Macroeconomics," Handbook of Macroeconomics, 2, 1789-1891.

Elsby, M., B. Hobijn, And A. ŞAhin (2015): "On the Importance of the Participation Margin for Labor Market Fluctuations," Journal of Monetary Economics, 72, 64-82. 
Flood, S., And J. PACAS (2016): "Using the Annual Social and Economic Supplement with Current Population Survey Panels," Minnesota Population Center Working Paper Series, 20164.

Gorbachev, O. (2016): "Has the Increased Attachment of Women to the Labor Market Changed a Family's Ability to Smooth Income Shocks," American Economic Review: Papers $E$ Proceedings, 106(5), 247-251.

Goux, D., E. Maurin, and B. Petrongolo (2014): "Worktime Regulations and Spousal Labor Supply," The American Economic Review, 104(1), 252-276.

Hansen, G. D. (1985): "Indivisible Labor and the Business Cycle," Journal of Monetary Economics, 16(3), 309-327.

Hryshko, D., C. Juhn, and K. MCCue (2014): "Trends in Earnings Inequality and Earnings Instability among U.S. Couples: How Important is Assortative Mating?," IZA Discussion Paper No. 8729 .

Jaimovich, N., H. Siu, and S. Pruitt (2013): "The Demand for Youth: Explaining Age Differences in the Volatility of Hours," American Economic Review, 103(7), 3022-3044.

Jaimovich, N., And H. E. Siu (2009): "The Young, the Old, and the Restless: Demographics and Business Cycle Volatility," American Economic Review, 99(3), 804-826.

Juhn, C., And S. PotTer (2007): "Is There Still an Added-Worker Effect?," Federal Reserve Bank of New York Staff Report, 310.

Keane, M. P. (2011): "Labor Supply and Taxes," Journal of Economic Literature, 49(4), 9611075 .

Keane, M. P., and R. Rogerson (2011): "Reconciling Micro and Macro Labor Supply Elasticities: A Structural Perspective," NBER Working Paper Series.

Krusell, P., M. Toshihiko, R. Rogerson, and A. Şahin (Forthcoming): "Gross Worker Flows over the Business Cycle," American Economic Review.

Lundberg, S. (1985): "The Added Worker Effect," Journal of Labor Economics, 3(1), 11-37. 
Madrian, B. C., And L. J. LefGren (1999): "An Approach to Longitudinally Matching the Current Population Survey," NBER Technical Working Paper No. 247.

Mankart, J., and R. Oikonomou (2016a): "Household Search and the Aggregate Labour Market," Review of Economics Studies, 0, 1-54.

(2016b): "The rise of the added worker effect," Economics Letters, 143, 48-51.

Peterman, W. B. (2015): "Reconciling Micro and Macro Estimates of the Frisch Labor Supply Elasticity," Economic Inquiry, 54(1), 100-120.

Shimer, R. (1998): "Why is the U.S. Unemployment Rate so much Lower?," NBER Macroeconomics Annual, 13, 11-61.

Smith, K. (2012): "Recessions Accelerate Trend of Wives as Breadwinners," Issue Brief 79, Carsey School of Public Policy.

Starr, M. A. (2014): "Gender, Added-Worker Effects, and the 2007 - 2009 Recession: Looking within the Household," Review of Economics of the Household, 12, 209-235.

Stephens, M. (2002): "Worker Displacement and the Added Worker Effect," Journal of Labor Economics, 20(3), 504-537.

Stock, J. H., And M. W. Watson (2003): Introduction to Econometrics, vol. 1. Pearson Education Inc.

Vespa, J., J. M. Lewis, and R. M. Kreider (2013): “America's Families and Living Arrangements: 2012," Population Characteristics U.S. Census Bureau, August. 


\section{Appendix}

\begin{tabular}{lcc}
\hline Industry & Married & Single \\
\hline Agriculture & 0.97 & 0.51 \\
Mining & 0.18 & 0.16 \\
Construction & 1.62 & 1.32 \\
Manufacturing & 6.98 & 7.70 \\
Wholesale & 11.14 & 12.64 \\
Transportation & 2.48 & 3.17 \\
Information & 1.82 & 2.22 \\
Finance & 8.47 & 7.76 \\
Professional \& Business & 9.40 & 10.57 \\
Education \& Health & 38.07 & 33.45 \\
Leisure \& Hospitality & 6.00 & 9.30 \\
Other & 4.85 & 5.25 \\
Public administration & 4.76 & 5.94 \\
Armed Forces & 0.002 & 0.004 \\
\hline
\end{tabular}

\begin{tabular}{lcc}
\hline Occupation & Married & Single \\
\hline Management, Business, Finance & 15.54 & 13.35 \\
Professional & 29.70 & 23.67 \\
Service & 15.78 & 23.30 \\
Sales & 8.87 & 10.32 \\
Office, Administration & 20.60 & 20.47 \\
Farming & 0.34 & 0.37 \\
Construction & 0.27 & 0.46 \\
Installation, Repair & 0.26 & 0.36 \\
Production & 3.71 & 5.02 \\
Transportation & 1.65 & 2.67 \\
Armed Forces & 0.002 & 0.004 \\
\hline
\end{tabular}

Table 16: Share of married and single women in

Table 15: Share of married and single women in different occupations different industries

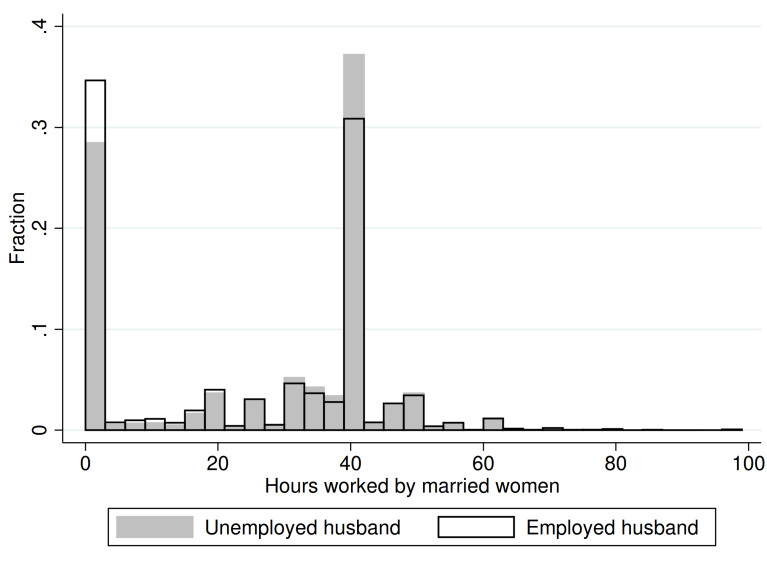

(a) Hours worked by all women

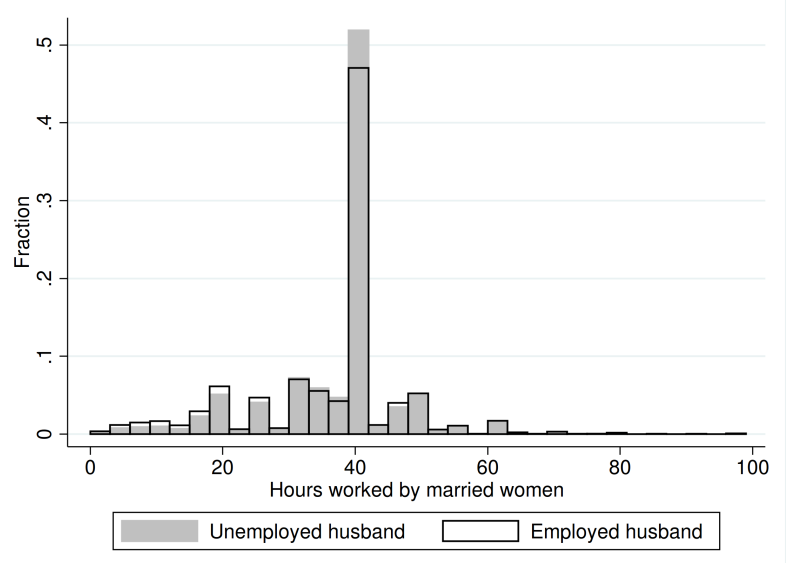

(b) Hours worked by working women

Figure 7: Hours worked of married women by employment status of husband (Definition of unemployment according to U-4) 


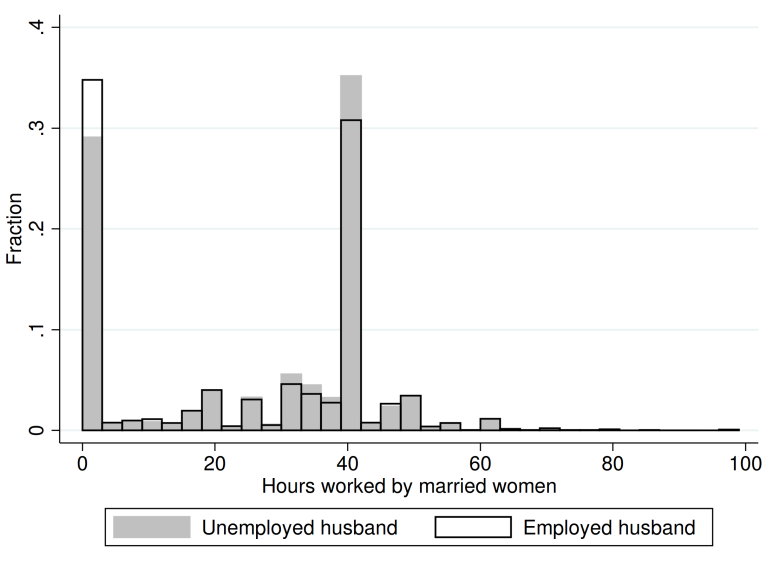

(a) Hours worked by all women

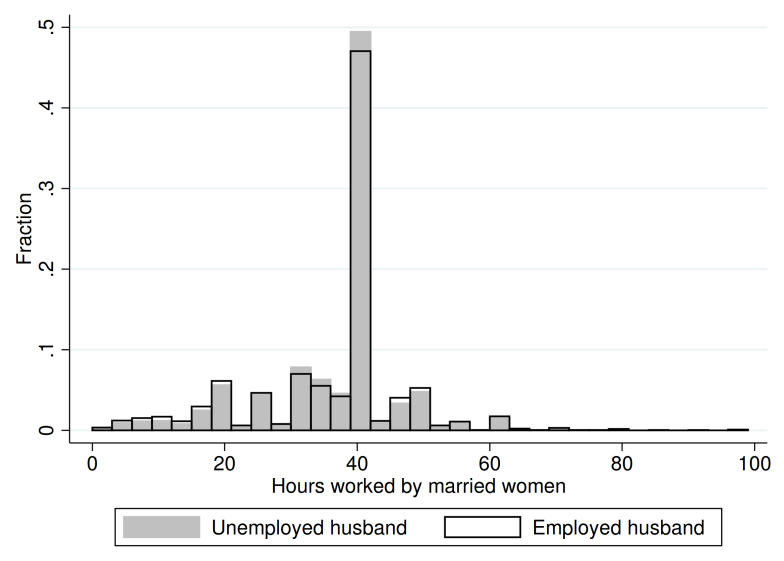

(b) Hours worked by working women

Figure 8: Hours worked of married women by employment status of husband (Definition of unemployment according to U-6)

\begin{tabular}{lcc|cc|cc|cc}
\hline & \multicolumn{3}{c}{ Contemporaneous } & \multicolumn{2}{c}{ Lagged 2 periods } \\
\hline & Married & \multicolumn{2}{c}{ Single } & Married & \multicolumn{2}{c}{ Single } \\
\hline & Men & Women & Men & Women & Men & Women & Men & Women \\
\hline \multicolumn{8}{c|c|c|c|c|c|c|c|cc}{} \\
\hline Cyclical Volatility & 0.1877 & 0.1087 & 0.2085 & 0.1996 & 0.0545 & 0.1097 & 0.1560 & 0.1541 \\
$R^{2}$ & 71.37 & 27.72 & 54.90 & 52.87 & 6.30 & 25.46 & 27.29 & 27.82 \\
\hline & \multicolumn{7}{c}{ Intensive and extensive margin } \\
\hline Cyclical volatility & 0.2344 & 0.0926 & 0.4298 & 0.4100 & 0.2946 & 0.2677 & 0.5799 & 0.5598 \\
$R^{2}$ & 33.78 & 10.00 & 32.19 & 31.95 & 48.73 & 73.26 & 52.33 & 53.14 \\
\hline
\end{tabular}

Table 17: Cyclical volatility for each gender and marital status combination with respect to lags of the unemployment rate (using band-pass filter) 